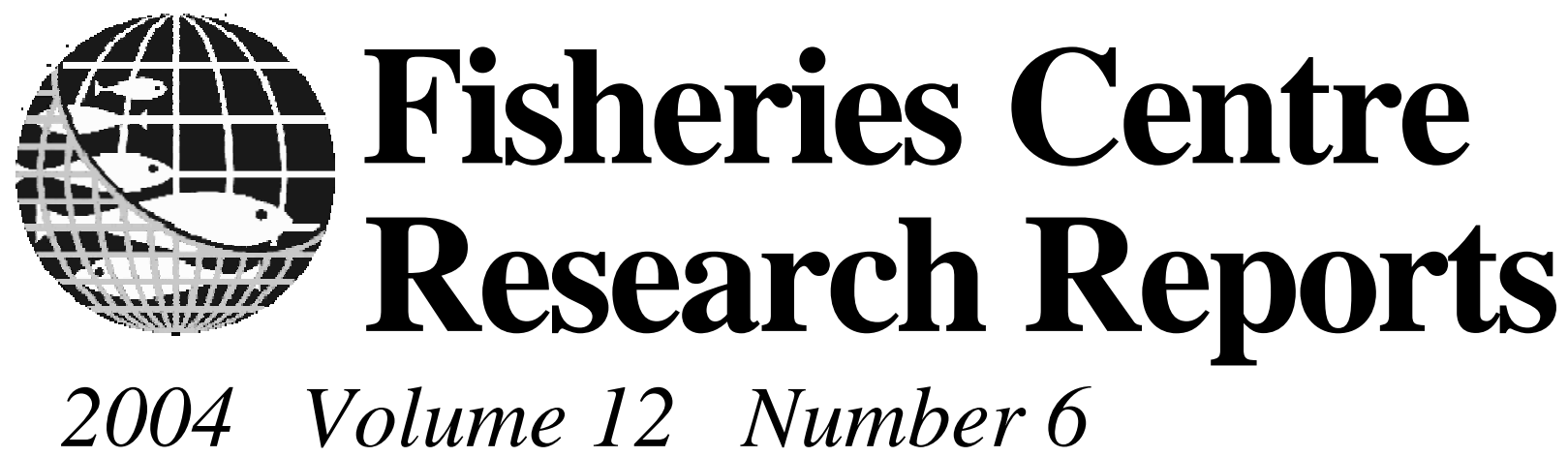

\title{
Fishing Gear Associated with Global Marine Catches
}

In collaboration with the

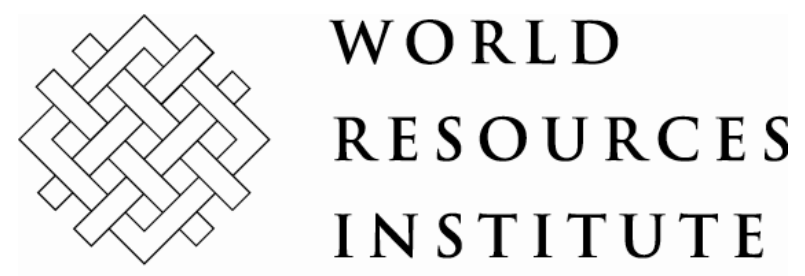

Fisheries Centre, University of British Columbia, Canada 


\title{
FISHING GEAR ASSOCIATEDWTH GLOBAL MARINE CATCHES
}

\author{
by \\ Reg Watson, Eriko Hoshino, Jordan Beblow, \\ Carmen Revenga, Yumiko Kura and Adrian Kitchingman
}

Fisheries Centre Research Reports 12(6)

32 pages (C) published 2004 by

The Fisheries Centre, University of British Columbia

2259 Lower Mall

Vancouver, B.C., Canada, V6T 1Z4

ISSN 1198-6727 


\title{
Fisheries Centre Research Reports Volume 12 Number 6 2004
}

\section{Fishing Gear Associated With Global MARine CATCheS}

\author{
Reg Watson, Eriko Hoshino, J ordan Beblow, Carmen Revenga, \\ Yumiko Kura and Adrian Kitchingman
}

\section{CONTENTS}

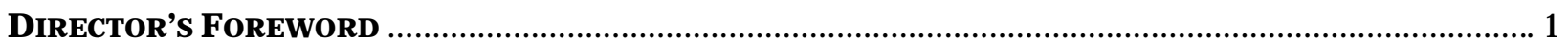

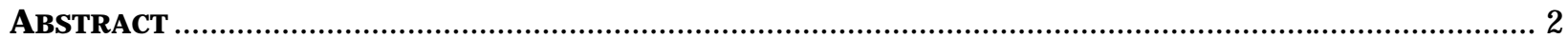

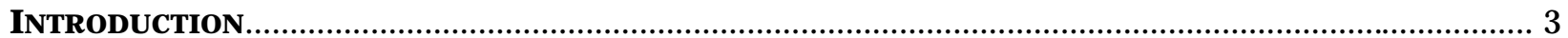

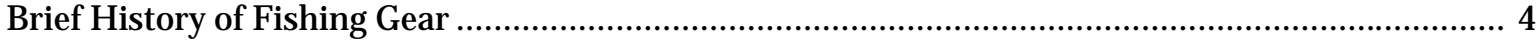

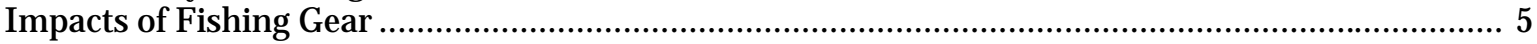

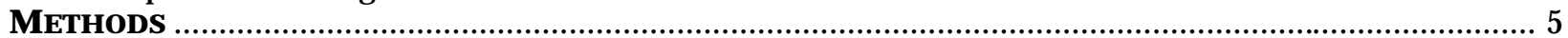

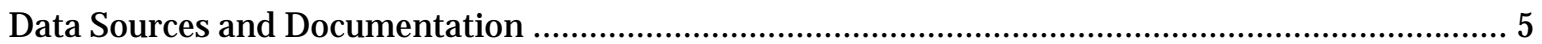

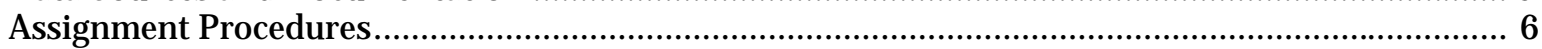

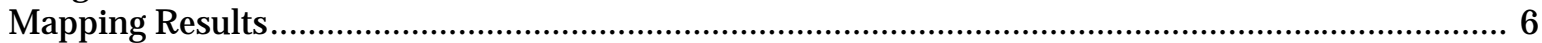

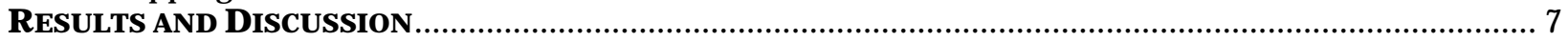

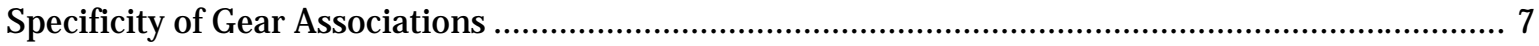

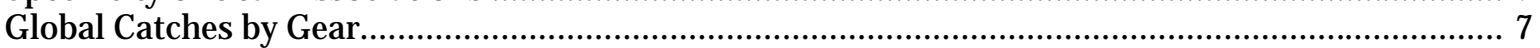

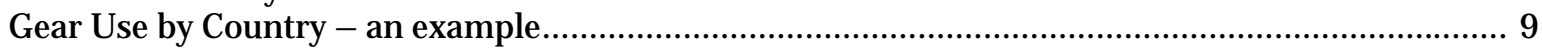

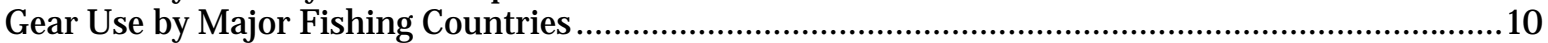

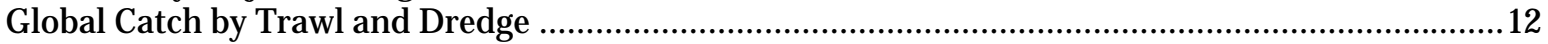

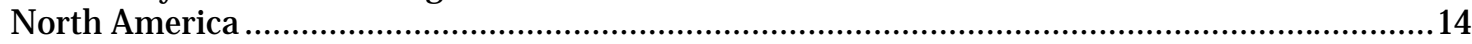

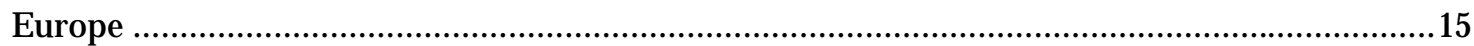

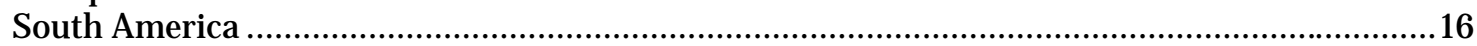

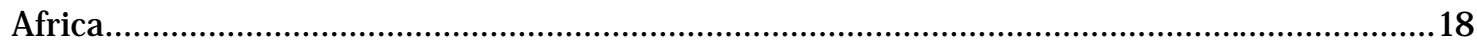

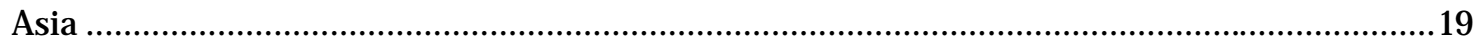

Proportion of Catch Using Trawl or Dredge Gear .............................................................................20

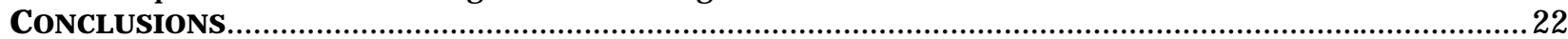

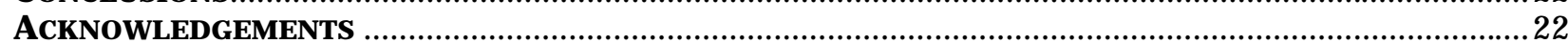

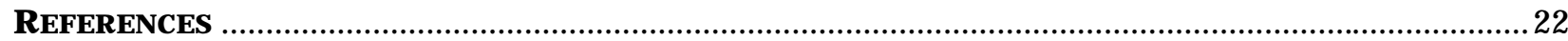

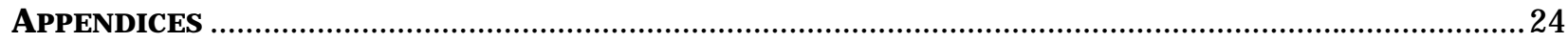

Annual average catch by fishing gear categories .............................................................................2 24

Fishing gear associated with capture of marine fish families...............................................................2

Catch associated with trawl or dredge gear (URL link only) ............................................................32

A Research Report from the Fisheries Centre at UBC

Fisheries Centre Research Reports 12(6)

32 pages (C) Fisheries Centre, University of British Columbia, 2004

FisHeRIES CENTRE RESEARCH REPORTS ARE ABSTRACTED IN THE FAO AQUATIC SCIENCES AND FISHERIES ABSTRACTS (ASFA) ISSN 1198-6727 



\title{
DIRECTOR'S FOREWORD
}

We humans have been catching fish and aquatic invertebrates since the very time that we emerged as a species, some 200,000 years ago, even if we do not believe, with Elaine Morgan, that we went through the 'aquatic ape’ phase she hypothesizes to explain some of our physiological and behavioural features.

Indeed, sophisticated bone harpoons were recovered in what is now the Congo (ex-Zaire) from riverine deposits dated 90,000 years ago (Yellen et al. 1995), i.e., before the first Homo sapiens left their native Africa, and long before Cro-Magnon people of present day Europe left in middens, and in form of carvings, proofs of their own, if surprisingly limited fishing activities (Clayet-Merle 1990).

Fast forward to the present: we are now using industrial and declassified military technology to catch fish, and our fishing activities span the globe. What before had protected marine resources from our effort at catching them - distance from the coast, depth, inclement weather - have all been vanquished by technology, and a global fish market has opened its insatiable maw. The result, unsurprisingly, is that the abundant fish resources we inherited from our ancestors of millennia ago have been dramatically reduced. We won't be able to pass on much to our descendents. How much will be left once the present mad rush of fisheries has completed its course will depend on how fast mitigating measures are put in place, and especially on how fast we will manage to phase out fishing gear that destroy the habitats of the species they exploit. I mean here mainly bottom trawls, whose increasing role is well documented in this report.

This report will be crucial to the required change: it is the first to document the scale of the issue we face.

Finally, in my other capacity as PI of the Sea Around Us project, I must express my pleasure at seeing the spatialized catch database developed by Reg Watson put to such novel (and obviously unanticipated) use as documented here. This supports, if needs be, that our investment in this large scale project was not only wise, but wildly successful. We look forward to the next surprise.

Cleyet-Merle, Jean-Jacques. 1990. La Préhistoire de la Pêche. Edition Errance, Paris.

Yellen, J. E., Brooks, A. S., Cornelissen, E., Mehlman, M. J. \& Steward, K. 1995. A middle stoneage worked bone industry from Katanda, Upper Semliki Valley, Zaire. Science 268: 553556.

\author{
DANiEL PAUly \\ DIRECTOR, UBC FISHERIES CENTRE
}




\section{ABSTRACT}

Fishing gears, instrumental to the fishing process, exert direct but often poorly documented impacts on marine communities and habitats. A database is described here that associates all global catch with fishing gear types allowing for the analysis of global fishing patterns. The fine spatial detail of the Sea Around Us project's catch database allows for the construction of maps showing subtle changes in the use of fishing gears annually since 1950. These maps are particularly useful to help assess the impact of fishing gears such as bottom trawls and dredges, which have been shown to have significant impacts on marine communities. Maps included in this report chronicle the expansion of these and other gears in ways that will inform debate over their impacts, and proved critical information to inform policy development and management choices. 


\title{
FISHING GEAR ASSOCIATED WITH GLOBAL MARINE CATCHES
}

\author{
Reg Watson $^{1}$, Eriko Hoshino ${ }^{2}$, Jordan Beblow ${ }^{1}$, Carmen Revenga ${ }^{2}$, Yumiko Kura ${ }^{2}$ and Adrian Kitchingman ${ }^{1}$ \\ ${ }^{1}$ Fisheries Centre, the University of British Columbia, 2259 Lower Mall, Vancouver, B.C., V6T 1Z4, Canada \\ ${ }^{2}$ World Resources Institute, 10 G Street, NE Washington, DC 20002 USA \\ r.watson@fisheries.ubc.ca; ehoshino@wri.org; j.beblow@fisheries.ubc.ca; carmenr@wri.org; yumiko@wri.org; \\ a.kitchingman@fisheries.ubc.ca
}

\section{INTRODUCTION}

Fishing is fundamental to coastal societies —an ancient activity that predates agriculture by thousands of years. For centuries, harvesting resources from the sea has been a source of sustenance and livelihood for millions of people. That is nearly as true today as it was a century ago. Yet, the nature of the fishing enterprise and the condition of the marine resources it relies on have changed radically in the last 100 years. During that time, the increase in the world's population and the concomitant economic development have brought a rapid expansion of commercial fishing and an overwhelming increase in our capacity to exploit fish stocks. This increased capacity and efficiency in the way we harvest fish is a direct result of a tide of new technology - from diesel engines to driftnets. Today greatly enlarged fleets equipped with fish-tracking sonar and factory ships with processing capabilities allow us to catch and process in any waters. The result has been a rapid depletion of key stocks, and sometimes, serious disruption and degradation of the marine ecosystems they live in.

The potential impacts from fishing go well beyond the targeted fish and often include other non-target animals as well as marine habitats, such as coral reefs and seagrass beds (Chuenpagdee et al. 2003). The cumulative effect of these impacts is, according to some scientists, the leading cause of current changes in the structure and functioning of coastal and marine ecosystems - more influential than climate change or water pollution (Jackson et al. 2001). To mitigate these harmful effects we not only have to fish less, we also have to change the way we fish by using alternative fishing methods and modified gear that lessen fishing's impacts on habitats and non-target species.

This is particularly true for some types of fishing methods such as bottom trawling and dredging. Bottom trawling and dredging are fishing methods that use gears to target fish and shellfish that inhabit ocean-bottoms, such as cods, scallops, shrimps, and flounders. These gears are considered to be 'active-towed gears', because they are actively dragged across the seabed by boats. Bottom trawls typically are large nets that are pulled across the seabed (http://www.mbayaq.org/cr/cr_seafoodwatch/sfw_gear.asp). The net is held open by the drag on large planing surfaces called boards or doors. These are usually heavily weighted and scour the bottom, while the bottom edge of the net tends to break off brittle bottom flora and fauna such as sponges and corals. Dredges are basically metal toothed bar or blades which dig into the seabed and scoop molluscs into a steel reinforced net. Bottom trawling and dredges are currently the most destructive gears in use, with the capacity to significantly disrupt benthic ecosystems in shallow as well as in deep sea waters. Although the degree of damage depends on a number of factors, including the frequency and intensity of trawling, and the type of seabed habitat, the destruction of seafloor habitats is a factor in the decline of some fishing stocks in heavily trawled areas (Watling and Norse 1998). The impact on benthic habitats and on bottom-living species can last decades or even centuries.

A recent study (2002) by the United States National Research Council (NRC 2002) on the impact of bottom trawling and dredging on the marine environment concluded that repeated trawling can shift marine species composition toward small opportunistic species—such as sea stars and small short-lived clams—while reducing the overall biomass of the area by removing aquatic vegetation and bottom-dwelling animals. The impact of shrimp trawling in the Great Barrier Reef Marine Park in Australia, for example, shows that a single trawl removes 5-25 percent of the bottom-dwelling organisms, and that repeated trawling has a cumulative impact (Poiner et al. 1998).

Another major impact of bottom-trawling is the large incidental catch of non-targeted species. Some of this bycatch is retained for sale, but a portion of it—often a large portion—is returned to the sea, usually dead or dying. In general, fishing gears that are towed along the bottom seem to have the highest bycatch rates. According to Alverson et al. (1994), the top 20 highest discard ratios (the ratio of target species to discards, by weight) are dominated by bottom 
trawl fisheries where only one-fifth or less of the catch is usually retained. A recent review of the different fishing gears used in the United States and their impact on ecosystems confirms that bottom-trawling rigs, bottom gillnets, and dredges have the worst ecological impacts (Morgan and Chuenpagdee 2003, Chuenpagdee et al. 2003).

Of course, fishing gears are an intrinsic part of the fishing process. Without these tools we would be very ineffective predators in the marine environment. Therefore any assessment of the impacts of fishing on marine environments requires, at a minimum, a time series of fisheries catches related to the gear that caught them. Global statistics are generally poor when it comes to identifying the species taken and the actual location where they are taken. Worse yet, are records of how much fishing 'effort' was expended, and even these seldom describe which type of fishing gear was used. In this paper, our goal was to associate the type of fishing gear employed with spatially disaggregated global fishing catch statistics (Watson et al. 2004) since 1950 and in this way start assessing the scope and intensity of potential impacts by different fishing gear on marine habitats and species. In particular we focused on mapping the distribution of trawling and dredging grounds and their change over time for the different fishing regions of the world.

To our knowledge, no database even similar to the one described here exists elsewhere. No other database exists that allows the catch taken by all commercial fishing gears to be mapped globally for the last 52 years, enabling the details of fishing patterns and their potential impacts to be revealed. Though this is already a powerful tool, it will be further refined and strengthened with additional expert input that will follow from its publication on the Internet. It will allow the interaction of fishing gears and critical habitats to be examined in time and with considerable spatial resolution. It promises to provide policy makers and user groups with the information they require to inform future debates over the impacts of fishing on the marine environment.

\section{Brief History of Fishing Gear}

Humans, ever the tool-makers and users, began using fishing gear earlier then any surviving artifacts. Collection of sedentary species involved beach combing and wading, methods still used today especially by women and children on the world's coral reefs and shallow shores (Vincent 2004). Some traditional mollusk fisheries in Spain still use beach combing tools today. For more active species such as most fin fishes, earliest methods were likely simple spears and clubs. Without human population pressures or depleted resources, these methods, though requiring energy and time, probably provided ample catch.

More sophisticated, but still within the capability of early humans, were simple nets, fixed or thrown, or fish traps made with wooden poles or even formed of rock or coral. Early fishers could also fashion baited hooks constructed of bone. With the advent of these 'passive' gears fishers did not have to attend to the fishing process continuously, and in some cases it would have been sufficient to simply make repairs and remove the harvest once a day or at the appropriate tidal cycle.

Craft suitable for use as fishing platforms enabled fishers to move from shore areas and to fish in better and less-used locations. The 'catchment' area for the supply of marine protein was greatly increased. They allowed fixed gear to be more elaborate and to extend its use further out to sea. It also facilitated the trade of seafood, dried or otherwise, along coastal areas and up rivers.

As human needs increased, so did our capacity to develop new technologies to catch fish and other marine animals more efficiently, as did our preservation techniques such as salting and drying. Critical to our success at harvesting more from the sea was our ability to travel further and faster, to employ larger gear, and to use a wider range of animals as food. Sailing, where winds were favourable, provided the propulsion for moving larger vessels and made it feasible to drag gear in the water. No longer did we have to attract fish to our fishing gear nor rely on their natural migrations. Following the advent of the steam engine this technology was scaled to fit larger wooden vessels making them maneuverable in a wider range of conditions then wind alone would allow. Propellers, steel hulls, diesel engines, and advanced navigational systems all allowed large fishing gear to be dragged and employed on the bottom hundreds of kilometers from port while refrigeration replaced ice to keep catch fresh. Power blocks and more powerful engines allowed the use of huge and heavy purse seine gear, capable of encircling entire schools of fast fish such as tuna, and capturing them despite their diving abilities (Sarhage and Lundbeck 1991). Now fishing gear is as technically advanced in some fisheries as the vessels themselves. Many have sensors to detect depth and to gather data, and some can be left and located from great distances for recovery. Some lobster traps can be returned to the surface via coded 
sonar command. Helicopters and underwater cameras are now commonplace in some fisheries. Global positioning systems (GPS) have provided a huge advantage in returning to productive areas, in sharing spatial information and in providing efficient and safe navigation.

Through the development and employment of technologies man can now fish in all but the deepest parts of the ocean (Pauly et al. 2003). All natural refugia are now accessible to modern fishing gear. Fleets fish from the currently iceguarded Arctic seas to those extremely stormy waters surrounding the Antarctic. Outside the limited areas claimed by coastal states there is little control over fishing activities.

\section{Impacts of Fishing Gear}

The obvious primary impact of fishing gear is to kill and catch fish for human use, either as direct food items or as processed fishmeal for livestock and aquaculture operations. For this purpose we have perfected fishing gears through millennia. Though not the topic of this report it must be said that some still find it surprising that fishing gear can kill enough fish, especially larger ones, such that marine ecosystems themselves have been significantly altered, but prefer to place the primary responsibility for these changes on climate change, population, or other second-order anthropogentic causes. While these agents act in concert, we hold that fishing, and hence fishing gear, still have at present a bigger impact on marine communities than climate change or toxic pollution events.

With the ability to drag heavy gear at high speeds (relative to the average marine inhabitant) came the capacity to create great damage and change to marine environments. Earliest dragged gears were not able to operate on reefs, rock or even 'rough ground'. The consequences of 'hooking up' on these rough surfaces were torn, damaged or lost gear, and sometimes, the loss of the vessel itself. As our gear became stronger and heavier, with steel chains replacing weighted ropes, pulled by much more powerful vessels, it became possible to fish in some rough areas. Indeed some of these areas initially provided good yields given that they were probably refugia of larger animals and even of juvenile stocks. Some trawling gear could even employ chains between vessels to 'clear' areas, and make them more 'suitable' for fishing. In this way the structure of the bottom was simplified. In tropical areas small reef patches were removed, including sea-fans, sponges etc. In some cases, the impact of this was to remove the nursery habitat for the very target of the fishery, eventually reducing yields. In many cases, however, the fisheries shifted to target animals lower down the food web just to keep the nets full (Pauly et al. 1998). Thus, bottom-dependent (demersal) fish declined, and as they did, so did the degree of predation they exerted on other animals such as shrimps. With a smooth bottom it became feasible, and even desirable, to target these shrimps through the use of specialized bottom trawl gear. This type of fishing favours animals that mature at small sizes and very quickly. The bottom sediments are turned over quickly and there is a 'rain' of bycatch from the surface as smaller fishes and crabs are discarded in high volumes.

\section{METHODS}

\section{Data Sources and Documentation}

For each taxon reported in the global catch database developed by the Sea Around Us Project (SAUP) based largely on FAO data (Watson et al. 2004), we attempted to record up to five different gears that were employed and their relative importance. Our research is based primarily on commercial gear. Artisanal gear types, however, were recorded when the artisanal fishery provided the bulk of the reference information for a species in a given family (e.g., Drums or Croakers - Sciaenidae). The search for gear associations with fish catches was primarily structured along taxonomic lines. That is, we attempted to find in books, journals, and on the Internet, documentation of the use of a particular gear to catch a particular species of fish, crustacean, or mollusk. If this was possible then we would attempt to qualify this association by the countries nominated, or the region (we used the 18 major FAO statistical areas), or the range of years described. The Internet proved a rich source of at least recent gear associations. For the major species there were many references available. Many fishing gear manufactures advertise their products by documenting which species are effectively targeted. Minor species were more problematic, but there were many webpages giving gear associations by broad groups of fishes. Often the region where the gear association exists was documented, but in other cases, we had to assume that references described at least the major fishing areas of the countries listed. The Internet is nothing but contemporary, dynamic and hence volatile. Often, there was no specific reference to the years when the gear was 
employed which we assumed to mean that the association currently exists and probably has existed for a number of years. Though regulations can change the use of fishing gears quickly, changes in gear usually take several years to be completed. Unless we found specific ranges of years (see Table 1) we assumed that all years were the same.

The coding system used was the hierarchical system described by von Brant (1984) as reported in Appendix 1. For each gear used to catch a given taxon, the database had provision to record a URL and also a PDF name of the reference material, ensuring proper documentation and future ease for updating and fact checking. When PDF were available these where downloaded and cached. Otherwise the materials linked to the URLs were captured as PDFs to ensure future availability. The database also allows the recording of the countries or group of countries (e.g. the European Union) that employed the gear for catching that particular taxon. In addition, we described time periods with different mixtures of gears even for the same country and taxon. Seldom were there more than three different gears employed to catch a taxon by a specified country in a defined region and time period.

\section{Assignment Procedures}

The gear database described above was used with an interpolation process to ensure that all catch records from our global catch database (Watson et al. 2004), regardless of taxon, country, region and year, would have documented fishing gear associations. Given that gear associations for most of the world's catches were available directly from the gear database described above it was possible to use a structured interpolation process to simply fill in missing cases. The general process of interpolation was one of replacing general gear associations with more specific ones where they were available. This process assumed that the type of animal (i.e. taxon) was the primary determinate of the gear used. Following this, in no particular order, were the country fishing and the FAO statistical area where the gear was employed. Lastly, we considered the year when the catches were reported. At each step in the interpolation process, the level of specificity in the documentation was recorded. If a more specific association for a catch record occurred in a subsequent step in the process, then this gear association, and its record of specificity, was overwritten. In this way, all catch records recorded in the global database were matched with the most specific and relevant gear association record in the gear database or weighted averages of these (weighted by their individual specificity) when several were available.

\section{Mapping Results}

The spatial database of global fisheries catch of the Sea Around Us Project (Watson et al. 2004, Watson et al. in press; www.seaaroundus.org) was used. This database comprises nearly half a billion records of catch rates for global halfdegree latitude and longitude spatial cells, for all reported taxa and countries from 1950 to 2001. The spatial database is based on a consolidation of several major data sources such as the FAO capture fisheries and its regional bodies, the International Council for the Exploration of the Seas (ICES) STATLANT database (www.ices.int/fish/statlant.htm), the Northwest Atlantic Fisheries Organization (NAFO; www.nafo.ca/), as well as data provided from the Canadian, United States, and other governments. Using this catch database and the gear association database described above, it was possible to associate all catches taken in each spatial cell with the appropriate fishing gear code. Maps of the use of fishing gear by year, country, or many other descriptors were then possible. 


\section{RESUltS AND DISCUSSION}

\section{Specificity of Gear Associations}

Following the assignment procedure described above, a global catch database resulted in which each catch record had up to five gear types and their relative importance. An analysis of the final gear associations reveals that the majority of catch records (based on tonnage) had an association based on a specific taxon, usually qualified by region Table 1 ). For more than half of total catch (tonnage) the country was also specified. In only a small number of cases were the range of years specified. Having all of these factors specified occurred for less than one percent of global catch by weight, however, within the range of years assessed (1950-2001) this is not considered a major weakness.
Table 1. Breakdown of global fisheries catch by the specificity of gear association available. Percent of catch by weight shown for each group.

\begin{tabular}{|c|c|c|c|c|}
\hline $\begin{array}{l}\text { What? } \\
\text { Taxon }\end{array}$ & $\begin{array}{l}\text { Where? } \\
\text { FAO area }\end{array}$ & $\begin{array}{l}\text { Who? } \\
\text { Country }\end{array}$ & $\begin{array}{c}\text { When? } \\
\text { Year }\end{array}$ & $\begin{array}{l}\text { Percent } \\
\text { of catch }\end{array}$ \\
\hline broad & - & - & - & 0.02 \\
\hline broad & X & - & - & 0.83 \\
\hline broad & - & X & - & 0.07 \\
\hline broad & $\mathrm{X}$ & $\mathrm{X}$ & - & 4.53 \\
\hline broad & - & $\mathrm{X}$ & $\mathrm{X}$ & 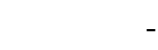 \\
\hline broad & $\mathrm{X}$ & - & $\mathrm{X}$ & 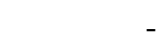 \\
\hline broad & $\mathrm{X}$ & $\mathrm{X}$ & $\mathrm{X}$ & \\
\hline specific & - & - & - & 30.08 \\
\hline specific & $\mathrm{X}$ & - & - & 18.62 \\
\hline specific & - & $\mathrm{X}$ & - & 3.11 \\
\hline specific & $\mathrm{X}$ & $\mathrm{X}$ & - & 42.72 \\
\hline specific & - & $\mathrm{X}$ & $\mathrm{X}$ & 0.01 \\
\hline specific & $\mathrm{X}$ & - & $\mathrm{X}$ & 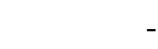 \\
\hline specific & $\mathrm{X}$ & $\mathrm{X}$ & $\mathrm{X}$ & 0.01 \\
\hline
\end{tabular}

Global Catches by Gear

Using the gear association database, it was possible to look at the specific or the general gear types used to capture the world's fish catches. For clarity, we will present results here grouped by eight general gear types, as there were in total 42 specific gears in total associated with global catches.

Since 1950, there has been a dramatic rise in the catch taken with both seine and midwater trawl gears (Figure 1). Though the catch using trawl and dredge gears has risen steadily, that of seine gear (which includes purse seine) has fluctuated considerably with the impact that climatic events such as El Niño have had on targeted stocks such as the Peruvian anchoveta (Engraulis ringens). At lower catch levels, but still significant, the catches from hook and line gear have been slowly overtaking that from gillnets, still at present, it is the fifth most important general gear type in terms of the contribution to the total catch. Much less, is the catch from dredge, traps and all other gears combined which we list here as 'other'. 


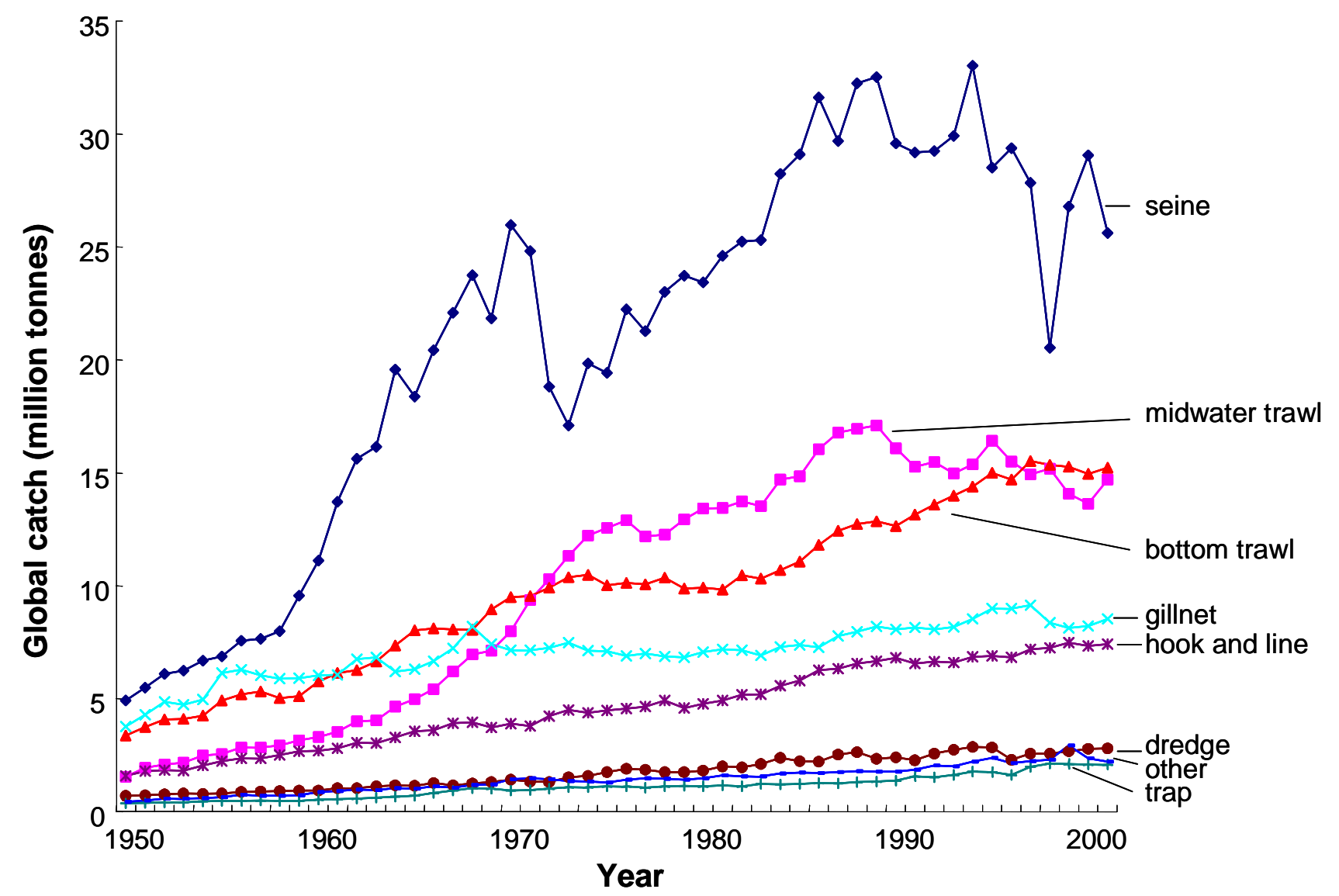

Figure 1. Annual global catch (million tonnes) taken by general fishing gear types

Despite the change in the relative rankings of general gear types suggested by catch associated with gears in Figure 1, it can be seen in Figure 2 that the relative catch taken by each gear type has remained remarkably constant since 1950 . An explanation may be that since 1950 very little historical data was available on the relative importance of each gear type, forcing us to assume that there has been relatively little change in their use. There has, however, been a change in the relative importance of the species being targeted since 1950, which has been well documented by Pauly et al.

(1998) and others. Therefore the constancy of relative gear use might exist simply because the use of fishing gears is maintained by fleets despite the changes in target species required when stocks collapse. 


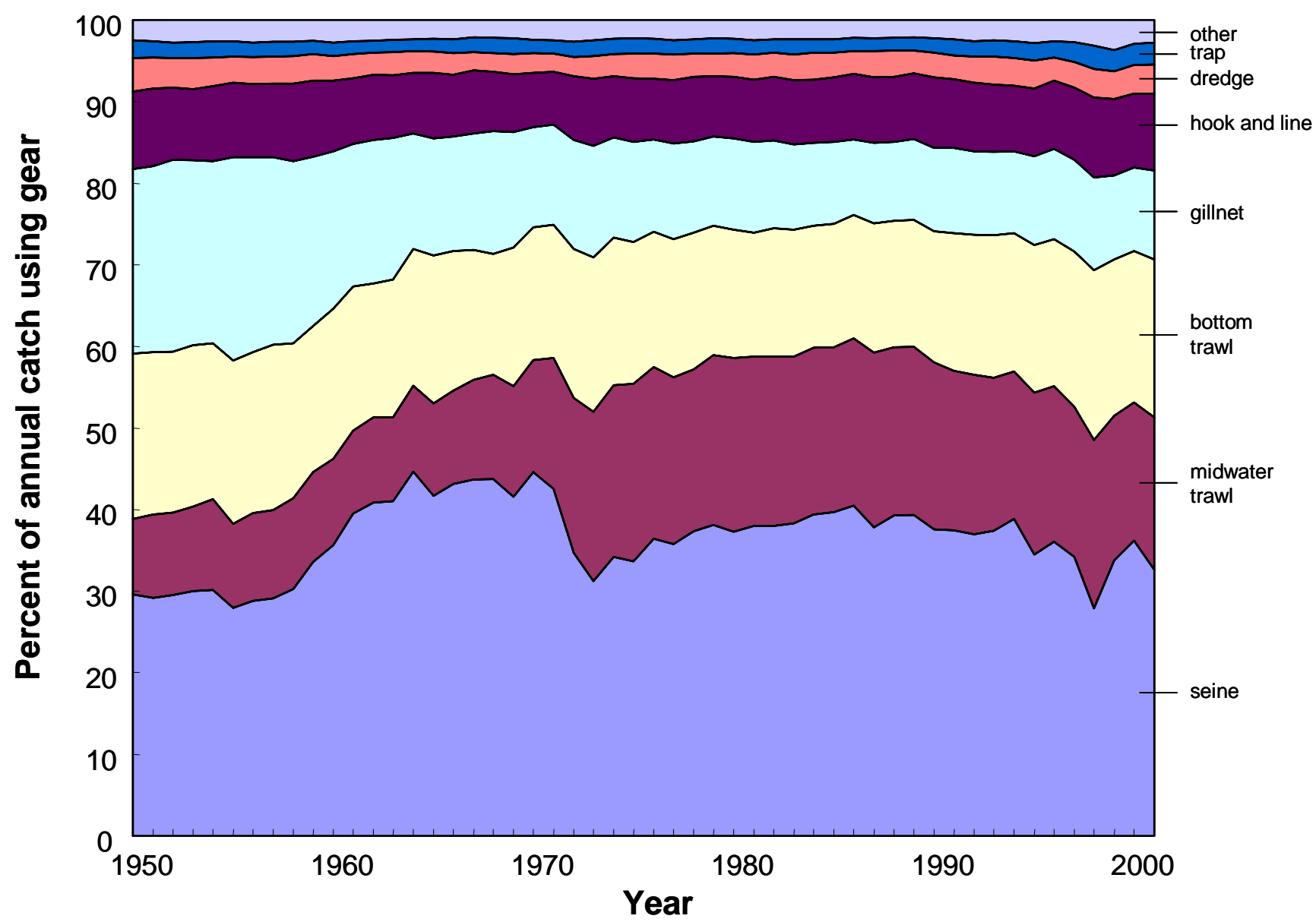

Figure 2. Percent of annual global catch taken by the top twenty gear types

Gear Use by Country - an example

The database we assembled also allows us to follow the use of gear by individual countries over time. In some there have been large changes in catch, which appear to be associated with the introduction of specific gear types. For example, the U.S. fleets (Figure 3) show a significant increase in catches at the time when the use of mid-water trawls was expanded in the mid-1980s. The dominant taxa associated with the use of this gear are small tunas, jacks and pompanos, taken predominately in subtropical and tropical waters. By the late 1980s more catch was reported for the species caught with mid-water trawl than for seine gear. Catch associated with seine gear here were largely caught using purse seine gear. Though there has been some expansion in catch by bottom trawl and dredge gear, the relevant importance of most gears has remained relatively static. 


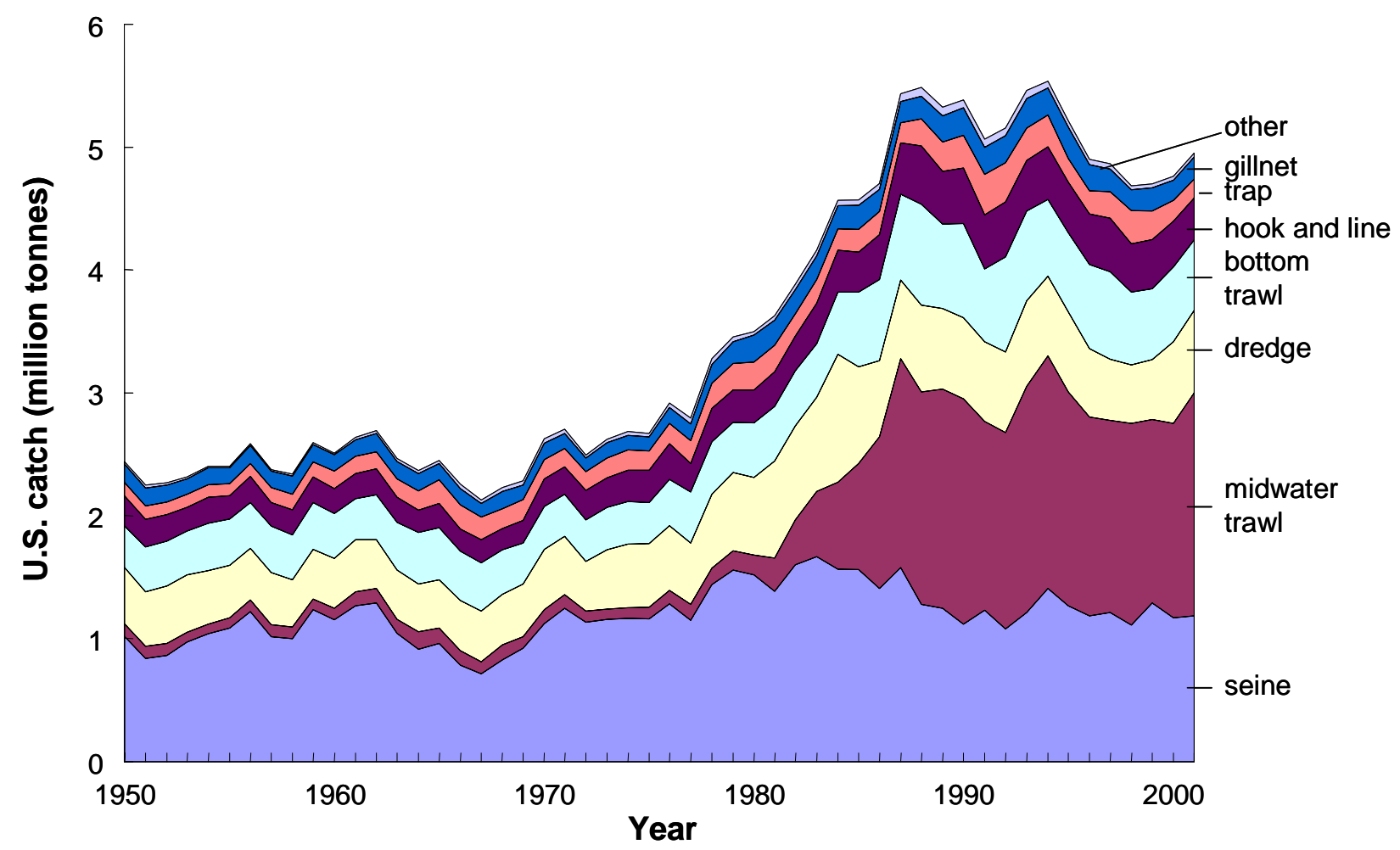

Figure 3. Annual catch (million tonnes) reported by the U.S. broken down by the top twenty gear types

\section{Gear Use by Major Fishing Countries}

In the 1950s, the catches by major countries were dominated by those taken by gillnet, seine and bottom trawl (Fig. 4). The relative catch by the major countries (as determined by bottom trawl catches in the 1950s) changed in subsequent decades, as did their relative use of gears. By the 1970s, the catch of these major fishing countries by gillnet gear decreased, while their use of midwater trawl gear increased. This trend, however, was not well reflected in the balance of catch taken by 'other' countries whose relative gear use was relatively static. By the 1990s, the importance of midwater trawl had decreased for most countries, with the exception of the nations comprising the former Soviet Union, where relative catch associated with midwater trawl actually increased. Seine gear, largely purse seine, continued to be important in the 1990s. This was particularly so for those relatively new leaders in fish catch such as Chile and Peru, whose fleets target Peruvian anchoveta (Engraulis ringens), used largely for reduction to fishmeal. 
a)
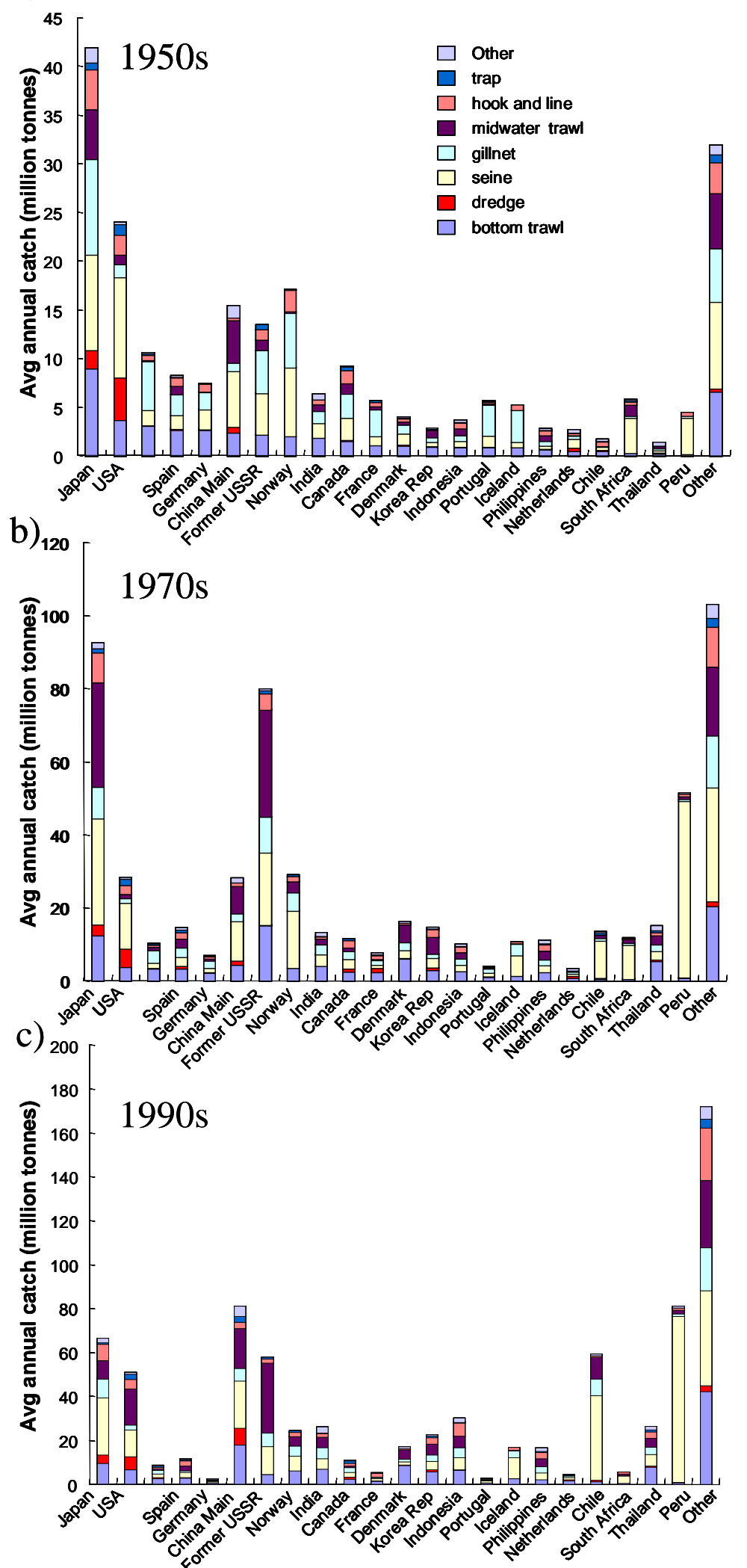

Figure 4. Catch (million tonnes) by major fishing countries broken down by general fishing gears for three decades a) 1950s, b) 1970 s and c) 1990s (ordered by the tonnage taken with bottom trawl gear in the 1950s). 


\section{Global Catch by Trawl and Dredge}

The reported composition of trawl and dredge catch is quite diverse. Broken down by major ISSCAAP groupings (i.e., the broad taxonomic groups reported by FAO), the largest catches were of shrimps and prawns, followed by several fish groups (Table 2). The mollusk groups such as clams, cockles, arkshells, scallops, pectens and oysters were taken predominately by dredge gear. The majority of the catch reported for some groups, largely pelagics, such as the group 'Tunas, Bonitos and Billfish', were taken by other gear types, such as purse seines.

When the major taxa taken globally by bottom trawl gear were examined (Table 3a), the list included both relatively valuable species such as Haddock, Saithe, shrimps and prawns, as well as those of lesser value, often used for reduction including anchovy, sand eel and ponyfish. Bivalves, dominated by scallops, oysters and clams, topped the catch taken by dredge gear globally (Table 3b).

Table 2. Breakdown of average global catch (tonnes) taken by bottom trawl, dredge or other gear into FAO ISSCAAP groups annually for the 1970s and 1990s.

\begin{tabular}{|c|c|c|c|c|c|c|}
\hline \multirow[b]{2}{*}{ ISSCAAP Group } & \multicolumn{3}{|c|}{ 1970s } & \multicolumn{3}{|c|}{ 1990s } \\
\hline & $\begin{array}{c}\text { Bottom } \\
\text { trawl }\end{array}$ & Dredge & Other & $\begin{array}{c}\text { Bottom } \\
\text { trawl }\end{array}$ & Dredge & Other \\
\hline Shrimps, prawns & $6,122,435$ & - & 125,715 & $2,385,189$ & - & 362,072 \\
\hline Marine fishes, (not elsewhere included) & $2,888,503$ & - & 781,301 & $1,203,034$ & - & 819,991 \\
\hline Sharks, rays, chimaeras & $2,051,973$ & - & 231,250 & 452,837 & - & 315,361 \\
\hline Squids, cuttlefishes, octopuses & 473,612 & - & 710,634 & $1,528,082$ & - & $1,351,549$ \\
\hline Salmons, trouts, smelts & 29,425 & - & $2,917,770$ & 32,509 & - & $2,107,267$ \\
\hline Lobsters, spiny-rock lobsters & 26,454 & - & 125,954 & 40,964 & - & 180,348 \\
\hline Craylets, squat lobsters & 24,180 & - & 85,338 & 5,478 & - & 66,441 \\
\hline Sea-spiders, crabs & 6,793 & - & 340,082 & 205,694 & - & 878,659 \\
\hline Krill, planktonic crustaceans & 5,514 & 346 & 1,906 & 5,122 & 1,326 & 169,793 \\
\hline Flounders, halibuts, soles & - & - & 202,757 & 833,190 & - & 201,686 \\
\hline Cods, hakes, haddocks & - & - & $9,035,767$ & $2,005,888$ & - & $8,457,450$ \\
\hline Redfishes, basses, congers & - & - & $2,729,229$ & $2,549,853$ & - & $3,847,493$ \\
\hline Jacks, mullets, sauries & - & - & $2,110,889$ & 327,645 & - & $2,675,150$ \\
\hline Herrings, sardines, anchovies & - & - & $16,762,081$ & $1,646,588$ & - & $23,738,200$ \\
\hline Tunas, bonitos, billfishes & - & - & $6,679,086$ & 914 & - & $9,097,174$ \\
\hline Mackerels, snoeks, cutlassfishes & - & - & $3,417,313$ & $1,133,641$ & - & $7,829,777$ \\
\hline Abalones, winkles, conchs & - & 48,718 & 55,431 & - & 89,719 & 74,097 \\
\hline Oysters & - & 396,565 & 1,204 & - & 243,544 & 1,476 \\
\hline Mussels & - & 179,948 & 304,374 & - & 93,881 & 229,813 \\
\hline Scallops, pectens & - & 344,358 & & - & $1,208,742$ & \\
\hline Clams, cockles, arkshells & - & 630,222 & 76,865 & - & 919,170 & 122,870 \\
\hline Sea-squirts and other tunicates & - & 1,166 & 4,190 & - & 1,663 & 4,895 \\
\hline Horseshoe crabs and other arac & - & 6 & 24 & - & 276 & . \\
\hline Sea cucumbers and other echinoderms & - & 37,937 & 39,808 & - & 13,042 & 104,452 \\
\hline
\end{tabular}


Table 3. Mean annual catch (tonnes) of the top twenty individual taxa taken by a) trawl and b) dredge gears for the period 1950 to 2002.

\section{a) Taxon taken by bottom trawl}

Japanese anchovy (Engraulis japonicus)

Threadfin breams (Nemipterus)

Sand eel (Ammodytes)

Haddock (Melanogrammus aeglefinus)

Saithe (Pollachius virens)

Cuttlefishes (Sepiidae)

Atlantic horse mackerel (Trachurus trachurus)

Anchovies (Stolephorus)

Northern shrimps (Pandalidae)

Sea catfishes (Ariidae)

Penaeus shrimps nei (Penaeus)

Argentine shortfin squid (Illex argentinus)

Yellowfin sole (Limanda aspera)

Slimys, Slipmouths, or Ponyfishes (Leiognathidae)

Giant tiger prawn (Penaeus monodon) *

Japanese jack mackerel (Trachurus japonicus)

Southern blue whiting (Micromesistius australis)

Northern prawn (Pandalus borealis)

Silver hake (Merluccius bilinearis)

Butterfishes (Stromateidae)

\section{b) Taxon taken by dredge}

Patinopecten yessoensis (Patinopecten yessoensis)

American cupped oyster (Crassostrea virginica)

American sea scallop (Placopecten magellanicus)

Atlantic surf clam (Spisula solidissima)

Japanese carpet shell (Ruditapes philippinarum)

Blue mussel (Mytilus edulis)

Ocean quahog (Arctica islandica)

Ark clams nei (Arca)

Pacific cupped oyster (Crassostrea gigas)

Northern quahog (=Hard clam) (Mercenaria mercenaria)

Half-crenated ark (Scapharca subcrenata)

Horned turban (Turbo cornutus)

Scallops nei (Pectinidae)

Cerastoderma edule (Cerastoderma edule)

Short neck clams nei (Paphia)

Brown mussel (Perna viridis)

Calico scallop (Argopecten gibbus)

Japanese hard clam (Meretrix lusoria)

Chamelea gallina (Chamelea gallina)

Cupped oysters (Crassostrea)
Mean annual catch (t)

544,134

458,159

456,464

439,469

426,230

347,676

340,822

313,892

278,001

229,379

218,768

214,017

160,696

155,759

139,976

137,315

121,767

119,377

112,756

103,244

330,108

208,054

133,439

127,611

107,664

79,950

74,332

46,762

44,090

41,757

38,519

34,009

33,007

30,625

30,131

29,092

27,544

27,471

26,051

20,080

* may include some aquaculture production 


\section{North America}

Mapped catch rates of all animals combined taken by bottom trawl and dredge gears reveals many changes since the 1950s (Fig. 5). In the 1950s the highest catch rates for either type of gear were along the mid to northern seaboard of the U.S (Fig 5a and d). By the 1970s, the bottom trawl and dredge fisheries had increased their ranges, particularly to northern Alaska and the west coast of Canada. Most notable here were the major bottom trawl fisheries for pandalid shrimps, King crabs (Paralithodes) and Yellowfin sole (Monochirus luteus). Also by the 1970s, bottom trawl fisheries along the northeast coast of North America for Haddock (Melanogrammus aeglefinus) and Sea catfishes (Ariidae) fisheries had declined, followed by the decline of fisheries for Silver hake (Merluccius bilinearis) by 1977.

Not withstanding individual declines, bottom trawl and dredge fisheries continued to expand each decade and peaked in the 1980s when major trawl areas included much of Alaskan waters, northern Washington, areas of the Gulfs of California and Mexico, as well as Nova Scotia. Along the North American northeast coast there were increases in catch of bottom trawled Yellowtail flounder (Limanda ferruginea), Summer flounder (Paralichtys dentatus), American plaice (Hippoglossoides platessoides), and pandalid shrimps. Along the southeast coast of North America and into the Gulf of Mexico, there were increases in the catch of bottom trawled Atlantic seabob (Xiphopenaeus kroyeri) and Sea catfishes (Ariidae). Along the west coast of the U.S. there were increases in trawled Pacific Ocean perch (Sebastes alutus), tonguefishes (Cyanoglossidae) and rockfishes (Scorpaenidae).

By the 1990s, catches from bottom trawling were in general decline. Along the northeast coast, there were reductions in Flounder catches. Along the southeast and into the Gulf of Mexico there were declines in catches of the Northern pink shrimp (Penaeus duorarum). Other bottom trawl fisheries that increased after the 1970s and along the northeast coast included fisheries for Northern prawn (Pandalus borealis), Greenland halibut (Reinhardtius hippoglossoides), American angler (Lophius americanus) and Piked dogfish (Squalus acanthus). Further south, there was an increase in trawl fisheries that took rays (Raja) and shrimp (Penaeus). Along the northwest coast and into Alaska increases in bottom trawled catches included Yellow sole (Monochirus luteus), Pacific cod (Gadus macrocephalus), the Lesser sand eel (Ammodytes marius) and Rock sole (Lepidopsetta bilineata). Along the southwest trawled catch of Common squid (Loligo) increased.

The catch of dredge fisheries in North America increased after the 1950s. The increases along the East coast included Atlantic surf clam (Spisula solidissima) in the north and the American cupped oyster (Crassostrea virginica) to the south. Along the northwest coast, there were increases in the Weathervane scallop (Patinopecten caurinus), Striped Venus (Chamelea gallina), Pacific cupped oyster (Crassostrea gigas), and Stimpson's surf clam (Spisula polynyma). Some dredge fisheries peaked before the 1990s; these include those for the Calico scallop (Argopecten gibbus) in the southeast and for scallops (Pectindae) in the southwest. By the 1990s, the dredge fishery for the American cupped oyster (Crassostrea. virginica) had declined and that for the Ocean quahog (Arctica islandica) had increased in the northeast. In the southwest there was a decline in dredged catches of the Pacific cupped oyster (C. gigas). 
a)

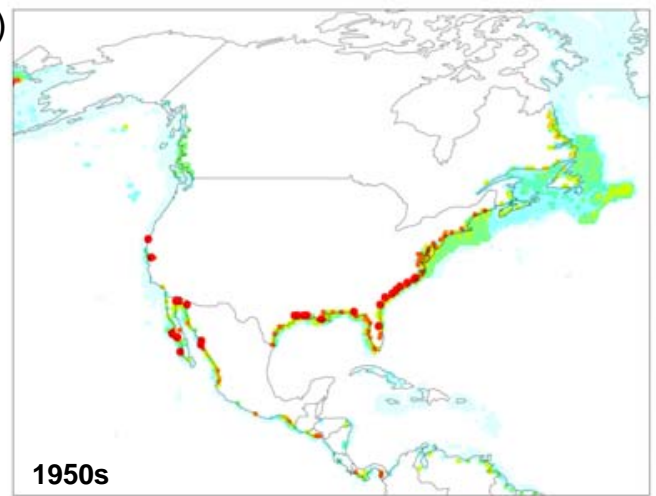

b)

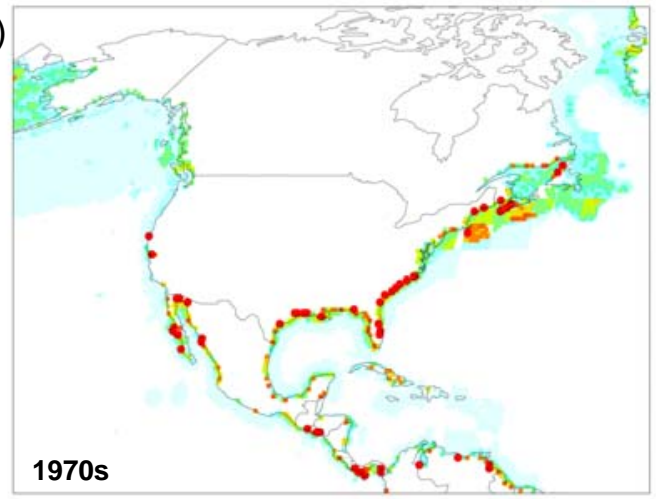

c)

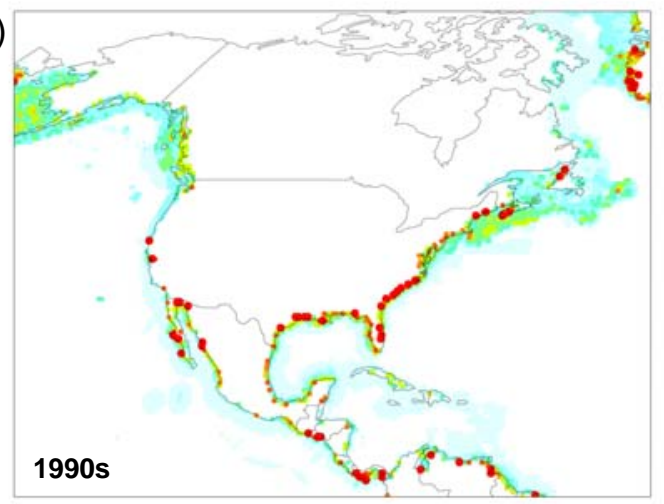

d)

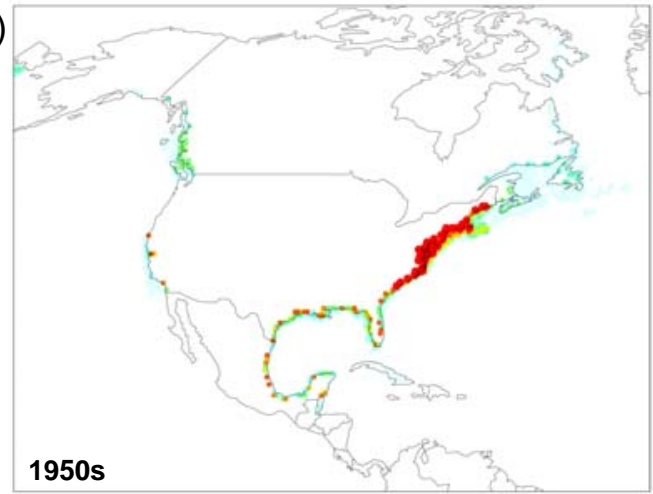

e)

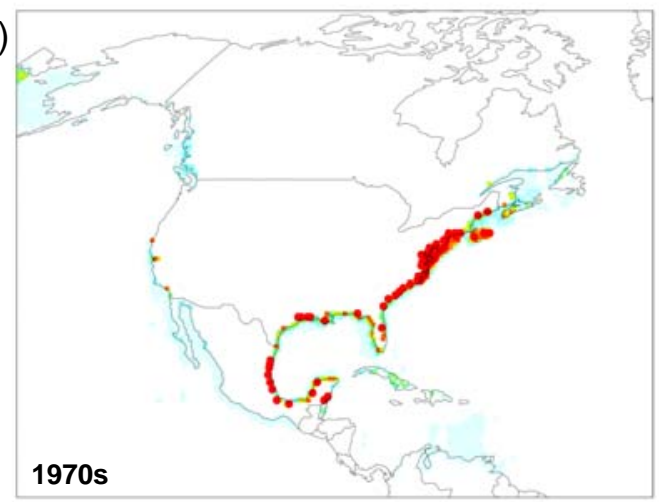

f)

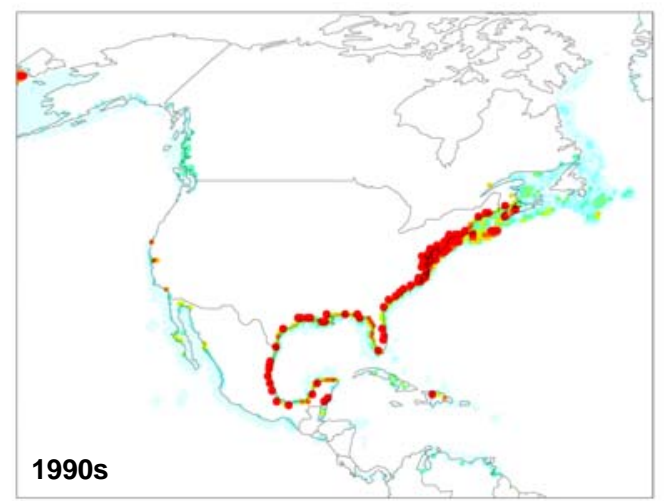

Catch rate $\mathrm{t} \cdot \mathrm{km}^{2} \cdot$ year $^{-1}$

$>15$

$10-15$

$7-10$

$5-7$

3- 5

$1.5-3$

$1-1.5$

$0.5-1$

$0.3-0.5$

$0.02-0.3$

Figure 5. Maps of catch rate (tonnes $\mathrm{km}^{2}$ year ${ }^{-1}$ ) associated with bottom trawl (a, b, and c) and dredge gears (d, e, and f) from North America for the 1950s, 1970s, and 1990s

\section{Europe}

The expansion of bottom trawl and dredge fisheries in Europe was as strong as in North American (Fig. 6). Though historically fisheries in the North Sea predate many others in the Western World, there was nevertheless a clear increase in intensity from the 1950s until about 1980.

Starting from the 1950s, there was an increase in bottom trawl catch of Sand lances (Ammodytes) and Atlantic horse mackerel (Trachurus trachurus). At this time, there was a decrease in catches of Ocean perch (Sebastes marinus). For dredge fisheries there were increases in catches of the Great Atlantic scallop (Pecten maximus).

There were peaks in the catch of some bottom trawl fisheries after the 1970s and these included those for Haddock (Melanogrammus aeglefinus), Saithe (Pollachius virens) and some sand lances. The dredge fisheries for the Blue 
mussel (Mytilus edulis) and Cupped oysters (Crassostrea) also peaked. Most expansion occurred offshore on the northern boundary of the North Sea.

In the 1990s there were increases in catches of bottom trawled Northern prawn (Pandalus borealis) and dredged Common cockle (Cerastoderma edule). By this time, the area of maximum trawl catch rates had contracted to the North Sea closer to Germany and Denmark (Fig. 6c).

a)

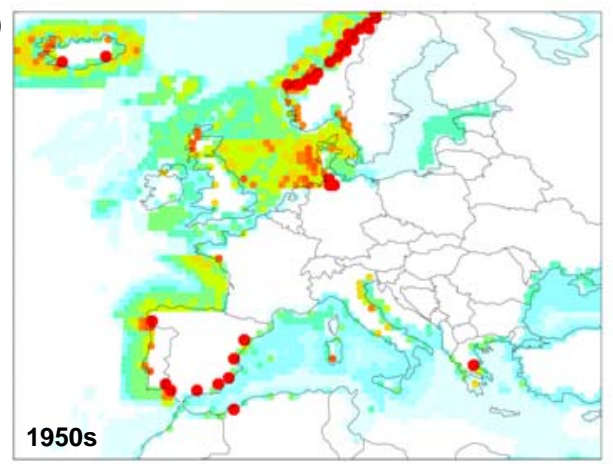

b)

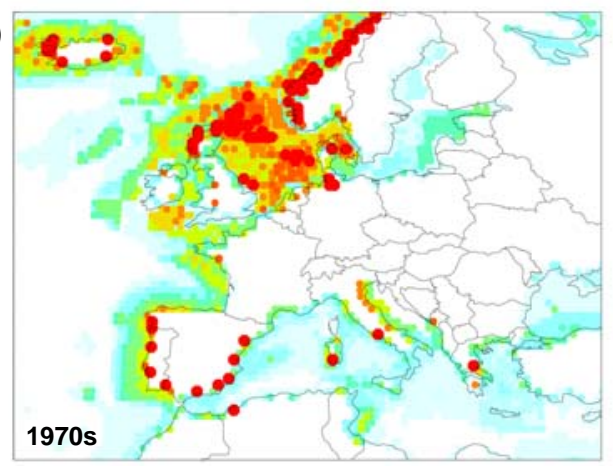

c)

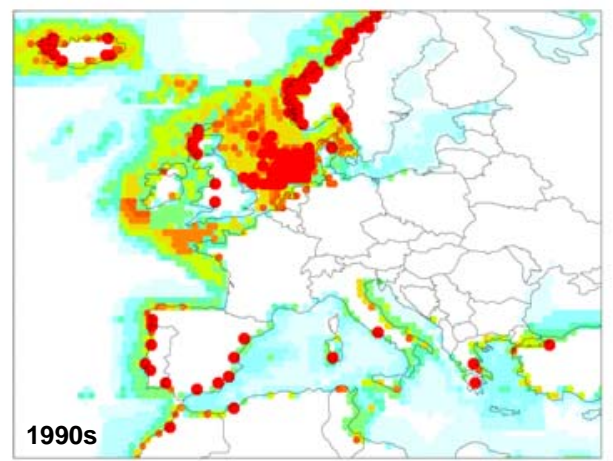

d)

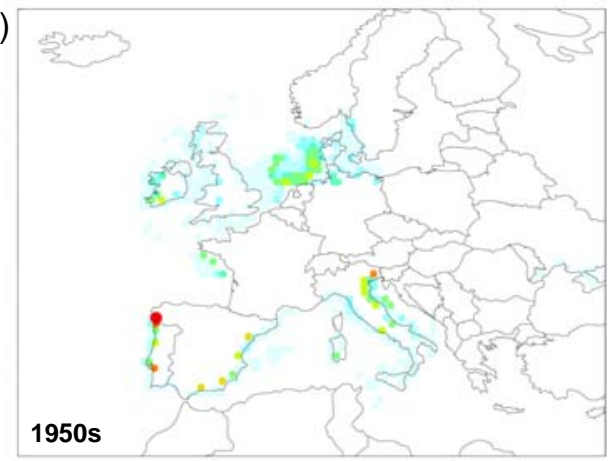

e)

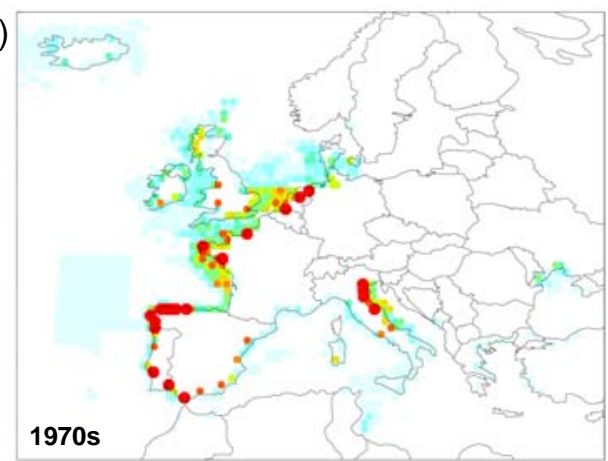

f)

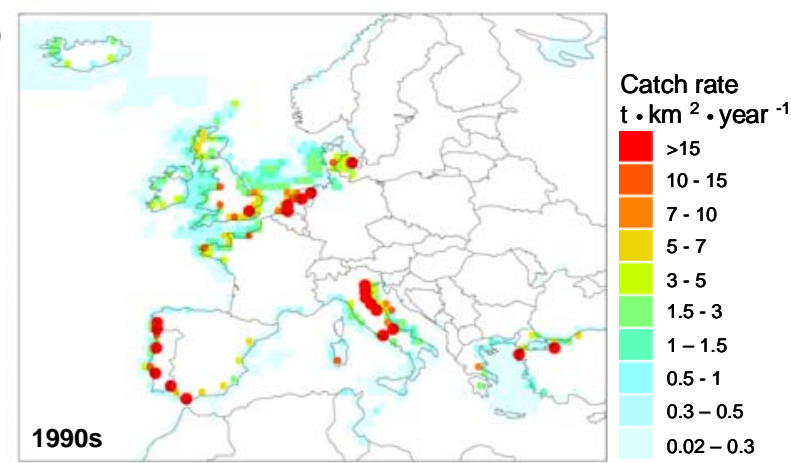

Figure 6. Maps of catch rate (tonnes $\mathrm{km}^{2}$ year ${ }^{-1}$ ) associated with bottom trawl (a,b, and c) and dredge gears (d, e, and f) from Europe for the 1950s, 1970s, and 1990s.

\section{South America}

Along the coasts of South America (Fig. 7), there has been a steady expansion in trawl and dredge-related catch up to and including the 1990s, especially along the coasts of Chile and Argentina. Along the coast of Argentina, the biggest bottom trawl expansion was the fishery for Argentine short-finned squid (Illex argentinus) in the mid 1980s. There was a steady expansion in the trawl fishery for the Argentine hake (Merluccius hubbsi) and Southern blue whiting (Micrormesistius australis). Along the west coast of South America, where purse seine gear dominates, the bottom trawl fisheries for Southern hake (Merluccius australis) and Peruvian hake (M. gayi peruanus) expanded after the 
1950s. In the 1990s, parallel to that along the Argentine coast, there was an increase in the catch of the Southern blue whiting (M. australis). Changes along South America since the 1950s were less than those shown in North America.

Dredge fisheries in this part of the world are minor compared to those based on other fishing gears. Along the Argentine coast there was an increase in the 1990s in catch of scallops (Pectinidae), and along the coasts of Peru and Chile, the dredge catch of Taca clam (Protothaca thaca), Peruvian calico scallop (Argopecten purpuratus), Carrot squat lobster (Cervimunida johni) and Slipper cupped oyster (Crassostrea iredalei) increased after the 1950s.

a)

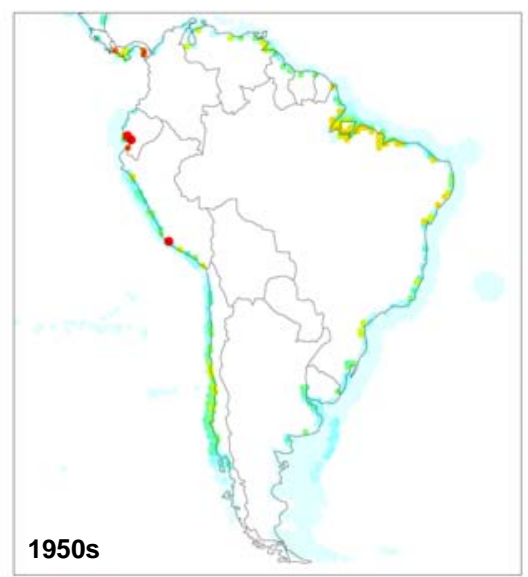

b)

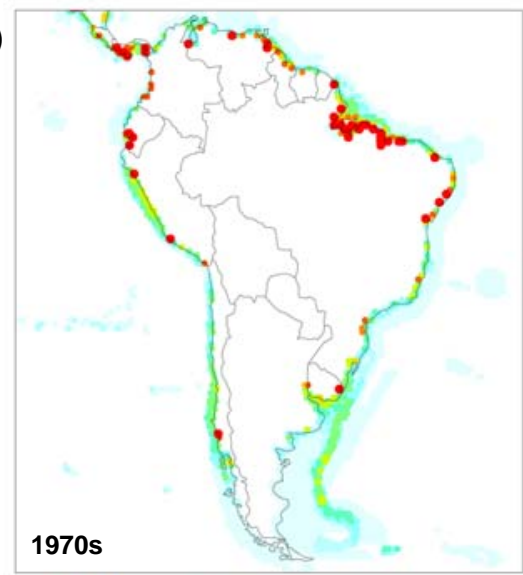

c)

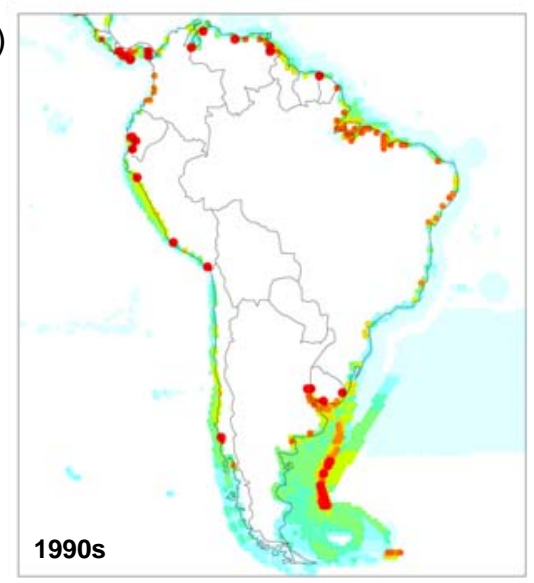

d)

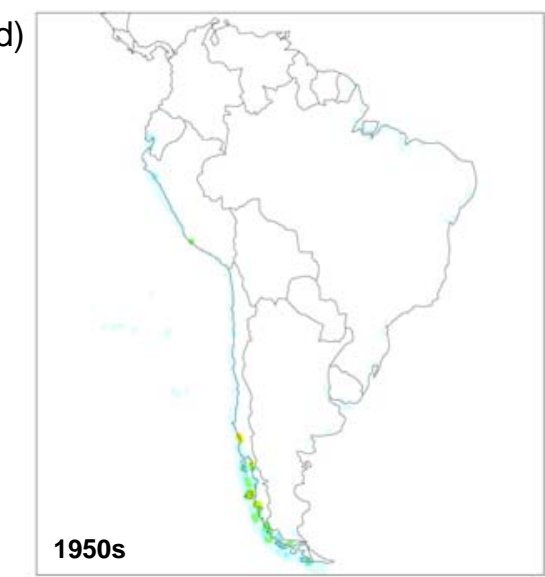

e)

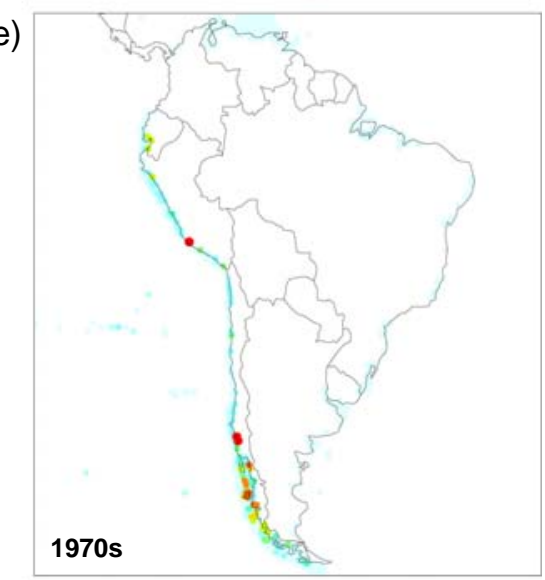

f)

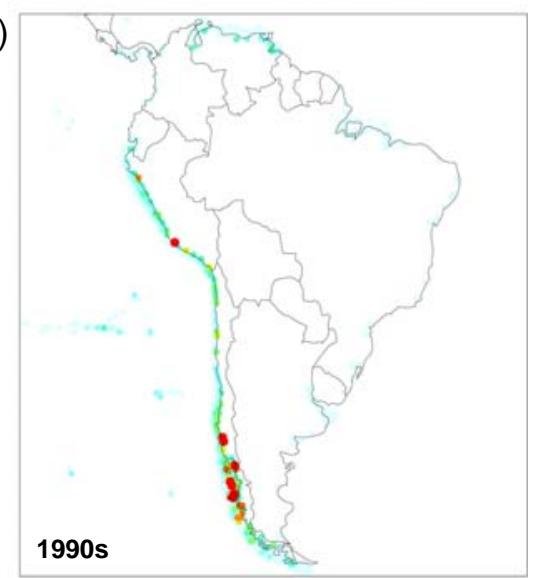

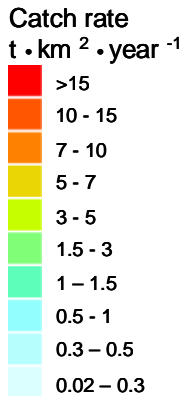

Figure 7. Maps of catch rate (tonnes $\mathrm{km}^{2}$ year ${ }^{-1}$ ) associated with bottom trawl (a,b, and c) and dredge gears (d, e, and f) from South America for the 1950s, 1970s, and 1990s. 
Africa

Along the coast of Africa there has been an expansion in bottom trawl catch rates first along the Western Sahara, Senegal, and the Gambia though by the 1970s the coast of Namibia and the south of Angola. Isolated areas of the Gulf of Guinea were also involved (Fig. 8). There was some increase along Mozambique and the north coast of Madagascar. Dredge fisheries were not significant in these time periods and therefore are not described here.

a)

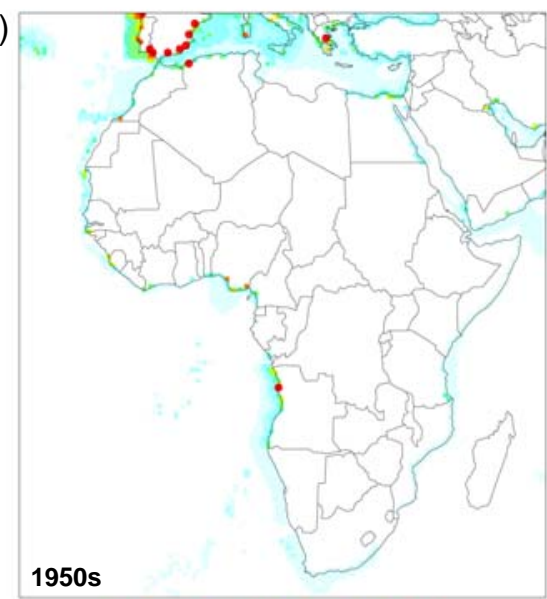

b)

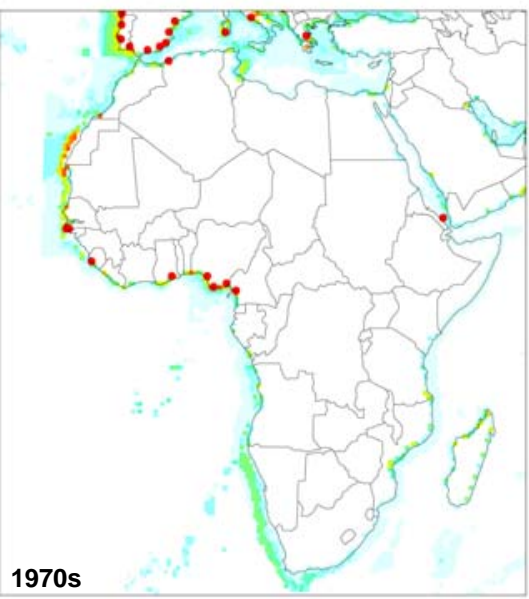

c)

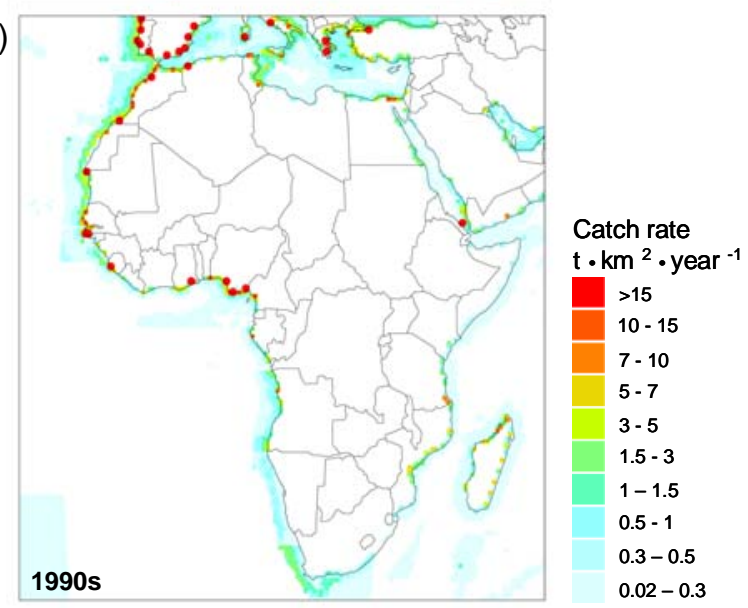

Figure 8. Maps of catch rate (tonnes $\mathrm{km}^{2}$ year ${ }^{-1}$ ) associated with bottom trawl from Africa for the a) 1950s, b) 1970s, and c) 1990s. 
Along NW Africa, there were increases in the trawled catches of cuttlefishes (Sepiidae) and the Common sole (Solea solea) after the 1950s. By the 1970s, there was a peak in catches of trawled Senegalese hake (Merluccius senegalensis), Large-eye dentex (Dentex macrophthalmus), porgies (Sparidae), rays (Raja) and Atlantic horse mackerel (Trachurus trachurus). Similarly along the SW coast of Africa, trawling for hakes, especially the Benguela hake (Merluccius polli) and for Dentex (Dentex spp) also peaked in the 1970s. As these declined in the 1990s, others increased including fisheries for octopus (Octopodidae) and Sea catfishes (Ariidae) in the NW, and Atlantic horse mackerel (T. trachurus) in the SW.

\section{Asia}

Maps of Asia show a steady expansion in reported catch rates for bottom trawl and dredge associated fisheries (Fig. 9). Throughout the region, there was an increase in the trawled catch of cuttlefish (Sepiidae) after the 1950s.

In the trawl fisheries of the East China Sea and the Sea of Japan there were declines in the catch of Yellow croaker (Larimichthys polyactis) after the 1950s. There were, however, increases by the 1990s in the catches of smaller species with lower trophic levels including Japanese anchovy (Engraulis japonicus), Gazami crab (Portunus trituberculatus), Southern rough shrimp (Trachypenaeus curvirostris), Yellowfin sole (Lamada aspera), and Golden threadfin (Nemipterus virgatus).

In the South China Sea, extending to the Arabian Sea and the west coast of India, there were increases after the 1950s in the trawl catches of Anchovies (Stolephorus spp), Giant tiger prawn (Penaeus monodon) (though some of the latter could be misreported aquaculture production). There were also increased bottom trawl catches along the coast of India of Sea catfishes (Ariidae) and the Southern rough shrimp (T. curvirostris), while shrimps from the family Crangonidae peaked in the 1970s. Trawled catches of some unidentified penaeid shrimp decreased in this area in the 1990s. Though the expansion appears to have peaked along the west coast of India by the 1970s, the coast of China showed a continued expansion of reported catch rates, as did those of Thailand, Malaysia and Indonesia.

Dredging was less important to parts of this region but was significant in inshore areas of the Sea of Japan and the East China Sea. Though catch of dredged Japanese carpet shell (Ruditapes philippinarum) peaked in the 1970s, others like the Japanese scallop (Patinopecten yessoensis) and Ark clams (Arca) continued to increase. Further south in the South China Sea, dredged catches of Brown mussel (Perna viridis) peaked in the 1970s, the Short-necked clams (Paphia) peaked in the 1980s, while Anadara clams (Anadara) continued to increase after the 1950s. 
a)

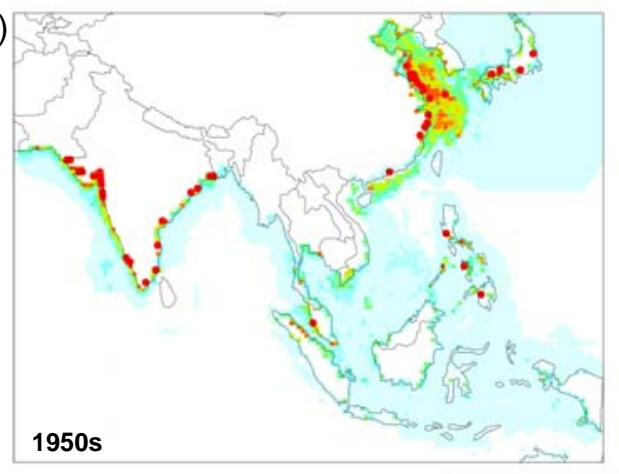

b)

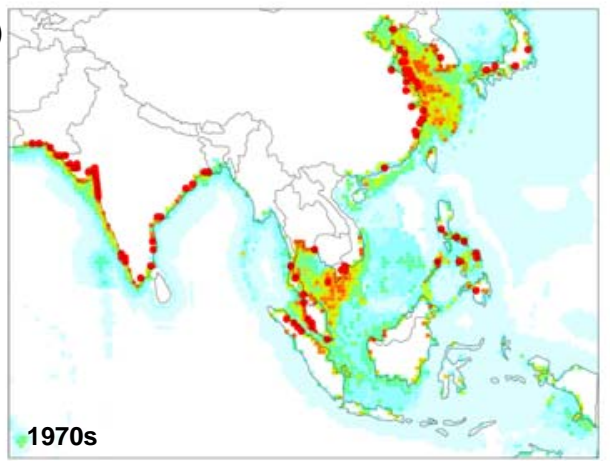

c)

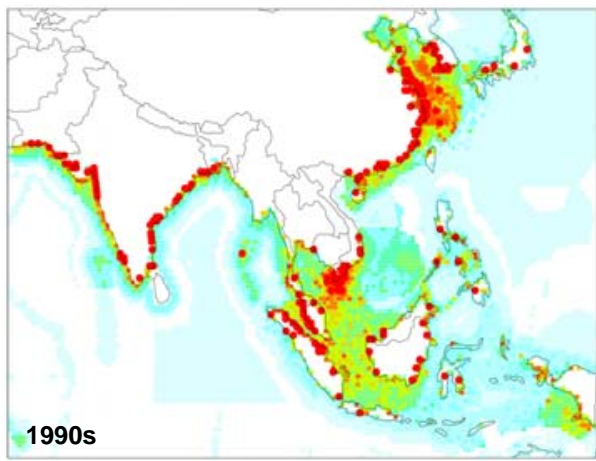

d)

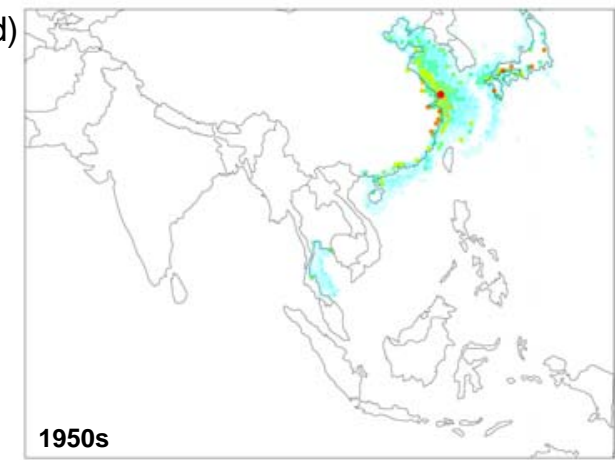

e)

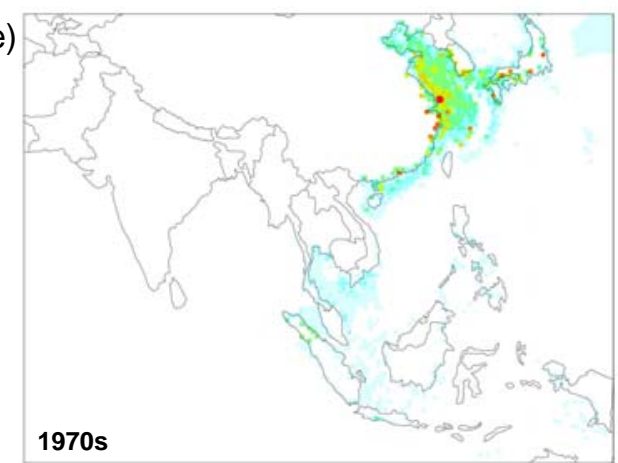

f)

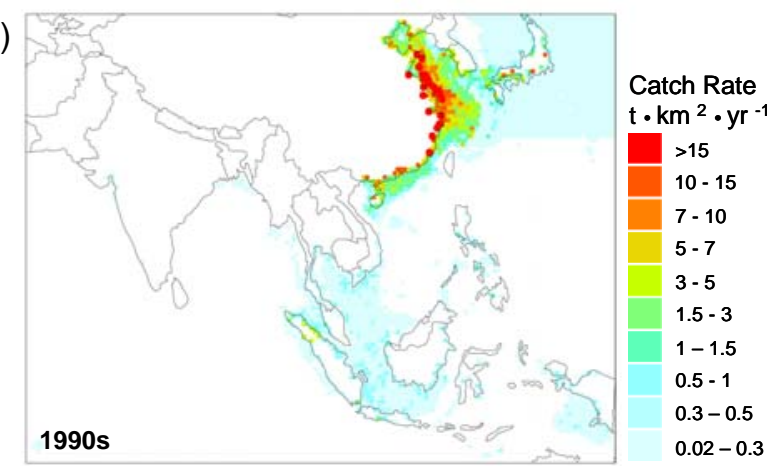

Figure 9. Maps of catch rate (tonnes $\mathrm{km}^{2}$ year ${ }^{-1}$ ) associated with bottom trawl (a,b, and c) and dredge gears (d, e, and f) from Asia for the 1950s, 1970s, and 1990s.

\section{Proportion of Catch Using Trawl or Dredge Gear}

The expansion of bottom trawl gear as the dominant gear associated with coastal fisheries catch in many areas of the world is evident in Fig. 10. This figure shows the proportion of all catch that is taken by bottom trawl. Even in the 1950s, for many areas of the world, this gear accounted for more than $40 \%$ of all reported catches. The association increased decade by decade with concentrations of trawling increasing in many locations. By the 1970s, trawl fisheries for American plaice (Hippoglossoides platessoides) along the west coast of Greenland and the Grand Banks of Newfoundland, Marbled rockcod (Notothenia rossii) along the coast of Antarctica and the Weddell Sea, Japanese anchovy (Engraulis japonicus) in Asia, and prawns, such as Banana prawn (Penaeus merguiensis), along the north coast of Australia dominated fisheries by all other gears. This expansion process continued, and by the 1990s, trawl fisheries for Blue grenadier (Macruronus novaezelandiae) around New Zealand and for the Argentine short-fin squid (Illex argentinus) along the coast of Argentina dominated fisheries using other gears. 

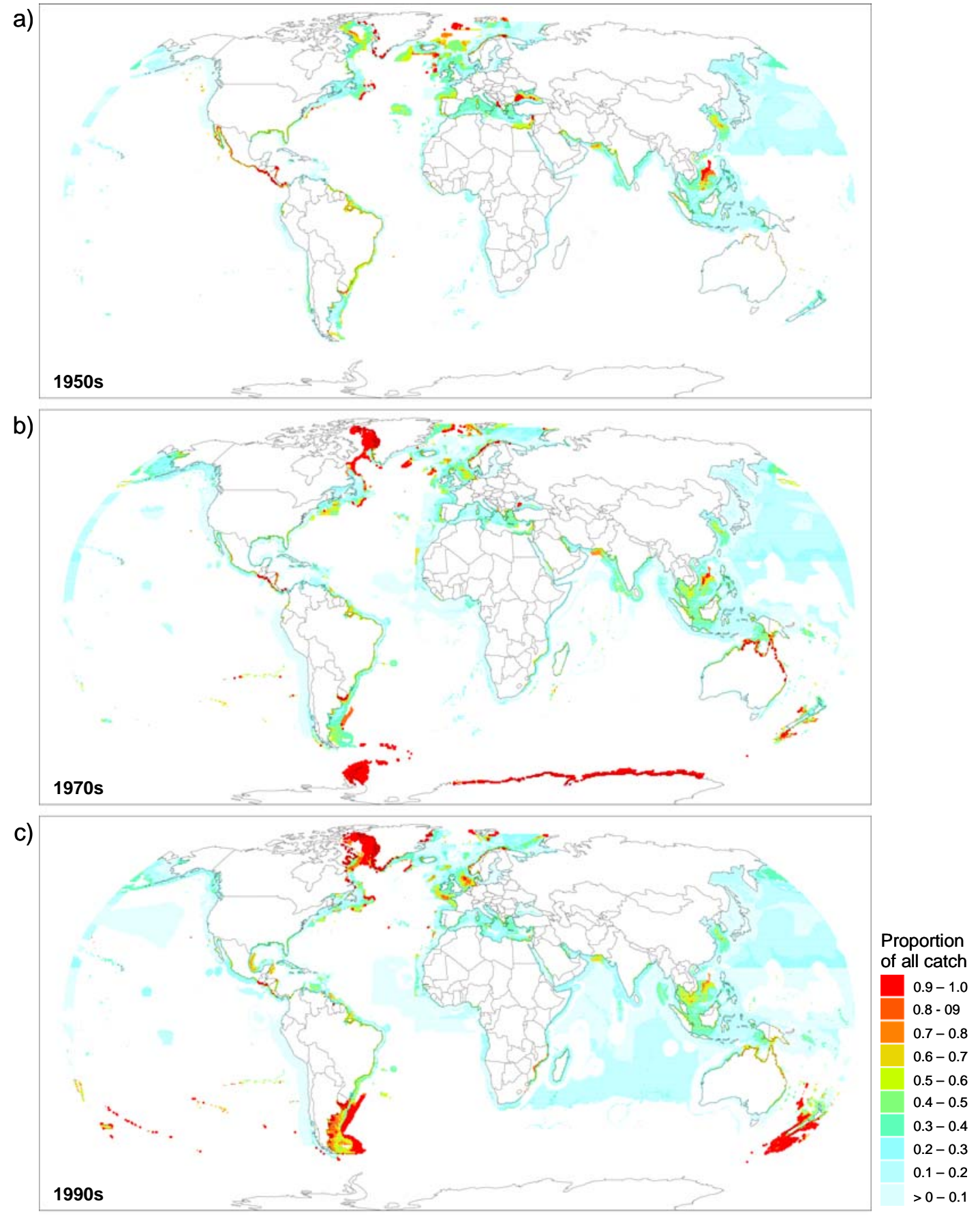

Figure 10. Map of the proportion of all reported catch associated with bottom trawl gear (excludes dredges) for the a) 1950s, b) 1970s, and c) 1990s. 


\section{CONCLUSIONS}

The usefulness of creating a database associating fishing gear with the catch of taxa with reference to the country fishing, the location of the fishing operation and the year, can be demonstrated by the interesting results that emerge when this database is associated with a global spatial database of fisheries catch such as the one developed by the Sea Around Us project. The combination allows all catch data since 1950 to be associated with the documented use of fishing gears, providing the ability to generate historical statistics in ways not seen before. In addition, it is possible to map the changing use of fishing gears globally. This type of detailed spatial information will be instrumental in investigating the changes in the impacts of fishing gears such as bottom trawl and dredging on marine habitats and communities.

Future versions of the fishing gear database will incorporate finer spatial and temporal precision than the version described here. In turn, this will allow an analysis of the overlaps and interactions between fishing gears and sensitive marine habitats such as seagrasses, coral reefs and seamounts. With the continued expansion of fishing gears into deeper waters and remote areas, this type of analysis will be extremely valuable to inform policy development and to help develop future management options.

\section{ACKNOWLEDGEMENTS}

This work was supported by the Sea Around Us Project, initiated and supported by the Pew Charitable Trusts of Philadelphia, and by the World Resources Institute, Washington, D.C., through funds made available by the Swedish International Development Cooperation Agency.

\section{REFERENCES}

Alverson, D.L., M.H. Freeberg, S.A. Murawski, and Pope, J.G. 1994. Global assessment of fisheries bycatch and discard. FAO Fisheries Technical Paper 339.

Chuenpagdee, R., Morgan, L.E., Maxwell, S.M., Norse, E.A., and Pauly, D. 2003. Shifting gears: assessing collateral impacts of fishing methods in the U.S. waters. Frontiers in Ecology and the Environment 10(1): 517-524.

Jackson, J.B.C., Kirby, M.X., Berger, W.H., Bjorndal, K.A., Botsford, L.W., Bourque, B.J., Bradbury, R.H., Cooke, R., Erlandson, J., Estes, J.A., Hughes, T.P., Kidwell, S., Lange, C.B., Lenihan, H.S., Pandolfi, J.M., Peterson, C.H., Steneck, R.S., Tegner, M.J. and Warner, R.R. 2001. "Historical overfishing and the recent collapse of coastal ecosystems.” Science 293: 629-638.

Morgan, L.E. and Chuenpagdee, R. 2003. Shifting gears: addressing the collateral impacts of fishing methods in U.S. waters. Washington DC: Island Press

NRC (National Research Council). 2002. Effects of trawling and dredging on seafloor habitat. Washington DC: National Academy Press.

Pauly, D., Alder, J., Bennett, E., Christensen, V., Tyedmers, P. and Watson, R. 2003. World fisheries: the next 50 years. Science 302(5649): 1359-1361.

Pauly, D., Christensen, V., Dalsgaard, J., Froese, R. and Torres, F.C. Jr. 1998. Fishing down marine food webs. Science 279:860-863.

Poiner, I., J. Glaister, R. Pitcher, C. Burridge, T. Wassenberg, N. Gribble, B. Hill, S. Blaber, D. Milton, D. Brewer, and Ellis, N. 1998. Final report on effects of trawling in the Far Northern Section of the Great Barrier Reef: 1991-1996. CSIRO Division of Marine Research, Cleveland, Australia.

Sarhage, D. and Lundbeck, J. 1991. A history of fishing. Springer-Verlag, Berlin, viii + 348 pp. 
Vincent, A. 2004. Reconciling fisheries with conservation in marine waters: the coral reef example. Keynote presentation at the $4^{\text {th }}$ World Fisheries Congress, Reconciling fisheries with conservation: the challenge of managing aquatic ecosystems, May 2-6 2004, Vancouver, Canada. In Press

von Brandt, A. 1984. Classification of catching methods In: Fish catching methods of the world. $3^{\text {rd }}$ Edition. Fishing News Books, Surrey, England.

Watling, L. and Norse, E.A. 1998. Disturbance of the seabed by mobile fishing gear: a comparison to forest clearcutting. Conservation Biology 12(6): 1180-1197.

Watson, R., Alder, J., Kitchingman, A., and Pauly, D. Catching some needed attention. Marine Policy. [in press]

Watson, R., Kitchingman, A., Gelchu, A. and Pauly, D. 2004. Mapping global fisheries: sharpening our focus. Fish and Fisheries 5: 168-177. 


\section{APPENDICES}

Appendix 1. Fishing gear categories modified from von Brandt (VB) (1984) showing the average annual catch in tonnes reported globally from 1950 to 2001 (inclusive) associated with each. Major gears are indicated in bold characters.

\begin{tabular}{|c|c|c|c|c|}
\hline General Gear & VB Code & Description & Catch (t) & \% Catch \\
\hline hand & 1 & 100 without gear & 84,420 & 0.15 \\
\hline hand & 1.1 & 110 grasping with hand & 102,033 & 0.18 \\
\hline hand & 1.2 & 120 by diving & 169,934 & 0.30 \\
\hline hook and line & 4 & 400 Lines & 71,511 & 0.13 \\
\hline hook and line & 4.2 & 420 with gorges or hooks & $2,638,000$ & 4.67 \\
\hline trap & 5 & 500 traps & 864,541 & 1.53 \\
\hline trap & 5.4 & 540 tubular traps & 69,279 & 0.12 \\
\hline trap & 5.6 & 560 trapping gear & 52,991 & 0.09 \\
\hline net & 7 & 700 bagnets & 320,824 & 0.57 \\
\hline dredge & 8.3 & 830 dredges & $1,654,110$ & 2.93 \\
\hline bottom trawl & 8.4 & 840 bottom trawls & $9,700,985$ & 17.17 \\
\hline midwater trawl & 8.5 & 850 mid-water trawls & $10,015,195$ & 17.73 \\
\hline seine & 9 & 900 seine nets & 252,944 & 0.45 \\
\hline seine & 9.2 & 920 genuine seine net & 42,154 & 0.07 \\
\hline seine & 10 & 1000 surrounding nets & 7,007 & 0.01 \\
\hline seine & 10.1 & 1010 lampara-like nets & 407,313 & 0.72 \\
\hline seine & 10.2 & 1020 purse seines & $19,303,406$ & 34.17 \\
\hline seine & 10.3 & 1030 ring nets & 4,643 & 0.01 \\
\hline liftnet & 12 & 1200 liftnets or dipnets & 15,178 & 0.03 \\
\hline liftnet & 12.1 & 1210 hand liftnets & 127,677 & 0.23 \\
\hline castnets & 13.2 & 1320 cast nets, with or without pockets & 85,404 & 0.15 \\
\hline gillnet & 14 & 1400 gillnets & $5,599,474$ & 9.91 \\
\hline gillnet & 14.1 & 1410 set gillnets & 453,085 & 0.80 \\
\hline gillnet & 14.2 & 1420 driftnets & 998,268 & 1.77 \\
\hline trammel & 15 & 1500 tangle nets & 11,447 & 0.02 \\
\hline trammel & 15.4 & 1540 trammel nets & 320,113 & 0.57 \\
\hline spear & 2.1 .3 & 213 raking devices & 104,645 & 0.19 \\
\hline spear & 2.1 .4 & 214 tongs & 11,930 & 0.02 \\
\hline bomb/chemical & 3.1 .2 & 312 explosives & 55,766 & 0.10 \\
\hline hook and line & 4.2.1 & 421 handlines & 512,775 & 0.91 \\
\hline hook and line & 4.2 .2 & 422 set lines & 159,349 & 0.28 \\
\hline hook and line & 4.2 .3 & 423 drift lines & 2,984 & 0.01 \\
\hline hook and line & 4.2.4 & 424 troll lines & 942,525 & 1.67 \\
\hline hook and line & 4.3.2 & 432 pilks or jigs & 113,945 & 0.20 \\
\hline hook and line & 4.3.3 & 433 squid hooks & 165,346 & 0.29 \\
\hline trap & 5.5 .1 & 551 pots & 57,244 & 0.10 \\
\hline trap & 5.5 .2 & 552 conical and drum-like traps & 14,712 & 0.03 \\
\hline trap & 5.5 .3 & 553 box-like traps & 745 & 0.00 \\
\hline trap & 5.6 .3 & 563 pound nets & 15,976 & 0.03 \\
\hline dredge & 8.3.1 & 831 hand dredges & 56,056 & 0.10 \\
\hline seine & 9.2 .1 & 921 beach seines & 455,831 & 0.81 \\
\hline seine & 9.2 .2 & 922 boat seines & 458,075 & 0.81 \\
\hline
\end{tabular}


Appendix 2. General fishing gear associated with the capture of families of marine fishes, crustaceans and mollusks. Percent of catch taken with each gear category from 1950 to 2001 inclusive is shown..

\begin{tabular}{|c|c|c|c|c|c|c|c|c|}
\hline Family & Seine & $\begin{array}{c}\text { Midwater } \\
\text { trawl }\end{array}$ & $\begin{array}{c}\text { Bottom } \\
\text { trawl }\end{array}$ & Gillnet & $\begin{array}{c}\text { Hook } \\
\text { and line }\end{array}$ & Dredge & Trap & Other \\
\hline Acanthuridae (Surgeonfishes, tangs, unicornfishes) & & & & 100.00 & & & & \\
\hline Acropomatidae (Lanternbellies, temperate ocean-basses) & & 33.70 & 29.44 & 21.99 & 14.87 & & & \\
\hline Albulidae (Bonefishes) & 14.48 & 1.58 & 18.64 & 19.52 & 37.71 & & 3.10 & 4.97 \\
\hline Alepocephalidae (Slickheads) & & & 35.61 & 21.99 & 6.96 & & 13.61 & 21.83 \\
\hline Alopiidae (Thresher sharks) & & & & 100.00 & & & & \\
\hline Ambassidae (Asiatic glassfishes) & 11.19 & & 62.43 & 13.24 & 13.14 & & & \\
\hline Ammodytidae (Sand lances) & 3.76 & & 84.78 & 3.77 & 7.69 & & & \\
\hline Anarhichadidae (Wolffishes) & & & 99.35 & & 0.65 & & & \\
\hline Anoplopomatidae (Sablefishes) & & & & & 100.00 & & & \\
\hline Apogonidae (Cardinalfishes) & & & 28.80 & & 37.25 & & & 33.95 \\
\hline Arcidae (Arcidae) & & & & & & 67.72 & & 32.28 \\
\hline Arcticidae (Arcticidae) & & & & & & 99.45 & & 0.55 \\
\hline Argentinidae (Argentines or herring smelts) & & & 100.00 & & & & & \\
\hline Ariidae (Sea catfishes) & & & 100.00 & & & & & \\
\hline Ariommatidae (Ariommatids) & & & & & & & 100.00 & \\
\hline Aristeidae (Aristeid shrimps nei) & & & 100.00 & & & & & \\
\hline Arripidae (Australian salmon) & 46.36 & 18.35 & & 17.13 & 1.78 & & 16.38 & \\
\hline Asteriidae (Starfishes nei) & & & & & & 47.21 & & 52.79 \\
\hline Atherinidae (Silversides) & 48.22 & 17.83 & 6.31 & 17.75 & 5.56 & & 3.34 & 0.99 \\
\hline Balanidae & & & & & & 37.92 & 0.15 & 61.93 \\
\hline Balistidae (Triggerfishes) & & 0.02 & 0.02 & & 0.02 & & & 99.95 \\
\hline Batrachoididae (Toadfishes) & & 7.74 & 39.91 & 40.86 & 11.49 & & & \\
\hline Belonidae (Needlefishes) & & & & & 100.00 & & & \\
\hline Berycidae (Alfonsinos) & 1.97 & 20.85 & 58.27 & 6.36 & 7.77 & & 3.48 & 1.30 \\
\hline Bothidae (Lefteye flounders) & & & 69.51 & 10.44 & 20.06 & & & \\
\hline Brachyura (Marine crabs nei) & & & & & & & 100.00 & \\
\hline Bramidae (Pomfrets) & & & 100.00 & & & & & \\
\hline Bregmacerotidae (Codlets) & 35.66 & 2.69 & 2.65 & 40.21 & 0.01 & & 0.01 & 18.77 \\
\hline Buccinidae (Buccinidae) & & & & & & 19.91 & 45.41 & 34.68 \\
\hline Caesionidae (Fusiliers) & & & & & & & & 100.00 \\
\hline
\end{tabular}




\begin{tabular}{|c|c|c|c|c|c|c|c|c|}
\hline Family & Seine & $\begin{array}{c}\text { Midwater } \\
\text { trawl }\end{array}$ & $\begin{array}{c}\text { Bottom } \\
\text { trawl }\end{array}$ & Gillnet & $\begin{array}{c}\text { Hook } \\
\text { and line }\end{array}$ & Dredge & Trap & Other \\
\hline Callianassidae & & & 100.00 & & & & & \\
\hline Callorhinchidae (Plownose chimaeras) & & & 71.14 & & 15.63 & & & 13.23 \\
\hline Cancridae (Honah crabs, rock crabs) & 10.71 & & 2.39 & & & & 86.90 & \\
\hline Caproidae (Boarfishes) & & 28.96 & 27.83 & 27.01 & 16.20 & & & \\
\hline Carangidae (Jacks and pompanos) & 20.98 & 35.52 & 14.99 & 17.81 & 4.75 & & 0.03 & 5.93 \\
\hline Carcharhinidae (Requiem sharks) & & & 19.91 & 40.41 & 39.68 & & & \\
\hline Cardiidae (Cockles nei) & & & & & & 35.41 & 0.01 & 64.59 \\
\hline Centracanthidae (Centracanthidae) & 66.63 & & 32.96 & 0.27 & 0.13 & & & \\
\hline Centriscidae (Snipefishes and shrimpfishes) & 65.75 & & 15.79 & 14.73 & 3.72 & & & \\
\hline Centrolophidae (Medusafishes) & 6.77 & 18.17 & 56.06 & 5.52 & 13.33 & & 0.15 & \\
\hline Centrophoridae (Centrophoridae) & & 0.01 & 28.65 & 2.41 & 68.93 & & & \\
\hline Centropomidae (Snooks) & & 15.52 & 5.66 & 73.55 & 2.30 & & & 2.97 \\
\hline Cetorhinidae (Basking sharks) & & 0.02 & 53.57 & 30.56 & 15.85 & & & \\
\hline Channichthyidae (Crocodile icefishes) & & & 100.00 & & & & & \\
\hline Cheilodactylidae (Morwongs) & 0.21 & 8.00 & 61.67 & 0.22 & 29.70 & & & 0.20 \\
\hline Chirocentridae (Wolf herring) & 87.77 & 0.45 & & 0.47 & 11.31 & & & \\
\hline Chlorophthalmidae (Greeneyes) & 0.53 & & 6.03 & 92.23 & 1.21 & & & \\
\hline Clupeidae (Herrings, shads, sardines, menhadens) & 78.82 & 8.47 & 0.45 & 8.46 & 3.20 & & 0.35 & 0.25 \\
\hline Congridae (Conger eels) & & & & & 100.00 & & & \\
\hline Coryphaenidae (Dolphinfishes) & 30.44 & & & 34.20 & 35.35 & & & \\
\hline Cottidae (Sculpins) & & 0.06 & 49.70 & 49.75 & 0.24 & & & 0.26 \\
\hline Crangonidae (Crangonid shrimps nei) & & & 83.64 & & & & & 16.36 \\
\hline Cyclopteridae (Lumpfishes and snailfishes) & & & 21.26 & 78.74 & & & & \\
\hline Cynoglossidae (Tonguefishes) & & & 100.00 & & & & & \\
\hline Dalatiidae (Sleeper sharks) & & & 89.32 & 6.29 & 4.39 & & & \\
\hline Dasyatidae (Stingrays) & & & 0.03 & & 99.97 & & & 0.01 \\
\hline Donacidae (Donacidae) & & & & & & 40.48 & & 59.52 \\
\hline Echeneidae (Remoras) & 44.44 & 22.22 & & 11.11 & 22.22 & & & \\
\hline Echinidae (Echinidae) & & & & & & & & 100.00 \\
\hline Elopidae (Tenpounders) & 13.86 & 9.77 & & 26.91 & 45.13 & & & 4.33 \\
\hline Ephippidae (Spadefishes, batfishes and scats) & & 1.30 & 11.24 & 47.43 & 38.88 & & 0.38 & 0.77 \\
\hline
\end{tabular}




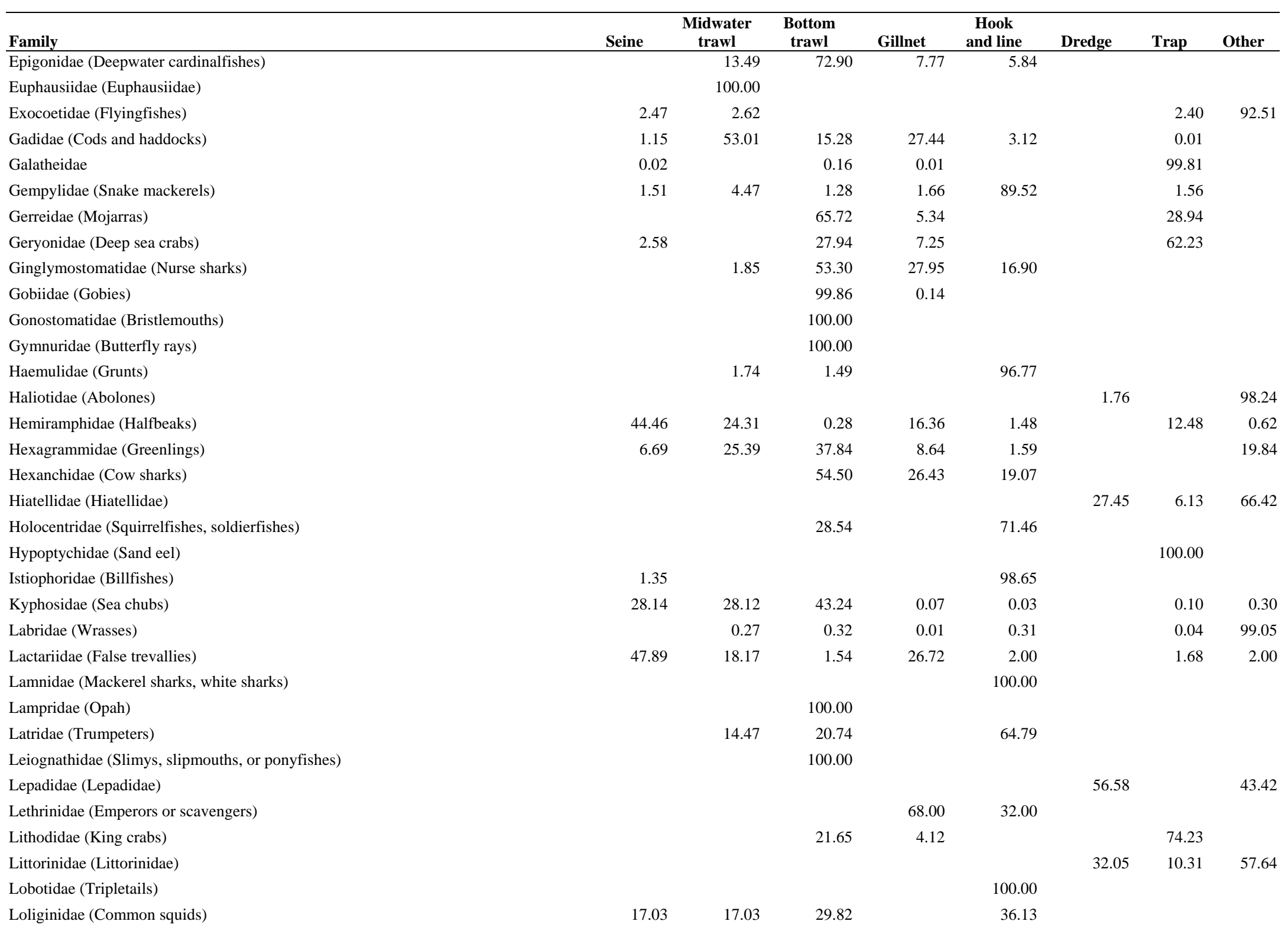




\begin{tabular}{|c|c|c|c|c|c|c|c|c|}
\hline Family & Seine & $\begin{array}{c}\text { Midwater } \\
\text { trawl }\end{array}$ & $\begin{array}{c}\text { Bottom } \\
\text { trawl }\end{array}$ & Gillnet & $\begin{array}{c}\text { Hook } \\
\text { and line }\end{array}$ & Dredge & Trap & Other \\
\hline Lophiidae (Goosefishes) & & & 57.33 & 19.95 & & & 2.77 & 19.95 \\
\hline Lotidae (Hakes and burbots) & & & 0.01 & & 99.99 & & & \\
\hline Lutjanidae (Snappers) & & & & 6.25 & 76.16 & & 17.58 & \\
\hline Macrouridae (Grenadiers or rattails) & & 7.44 & 81.58 & & 10.98 & & & \\
\hline Mactridae (Mactra surf clams) & & & & & & 99.66 & & 0.34 \\
\hline Majidae (Majidae) & & & & & & & 100.00 & \\
\hline Malacanthidae (Tilefishes) & 2.21 & 40.25 & 34.88 & 8.35 & 4.76 & & 0.28 & 9.27 \\
\hline Megalopidae (Tarpons) & 19.90 & 3.71 & & 18.05 & 58.34 & & & \\
\hline Melamphaidae (Bigscale fishes or ridgeheads) & & & 100.00 & & & & & \\
\hline Melongenidae (Melongenidae) & & & & & & & 100.00 & \\
\hline Menidae (Moonfish) & & & & 100.00 & & & & \\
\hline Merlucciidae (Merluccid hakes) & & 29.40 & 40.27 & 10.15 & 20.18 & & & \\
\hline Mesodesmatidae (Mesodesmatidae) & & & & & & 31.46 & & 68.54 \\
\hline Molidae (Molas) & 32.00 & & & & 68.00 & & & \\
\hline Monacanthidae (Filefishes) & & & & & 100.00 & & & \\
\hline Moronidae (Temperate basses) & 9.84 & 10.10 & 25.98 & 19.68 & 22.33 & & 12.08 & \\
\hline Mugilidae (Mullets) & 19.24 & 0.62 & & 60.35 & & & 19.79 & \\
\hline Mullidae (Goatfishes) & & 0.67 & 0.68 & 98.43 & 0.21 & & & \\
\hline Muraenesocidae (Pike congers) & & & 19.32 & & 45.76 & & 18.58 & 16.35 \\
\hline Muraenidae (Moray eels) & & 1.21 & 1.29 & & 47.40 & & & 50.10 \\
\hline Muraenolepididae (Eel cods) & 10.95 & 11.74 & 31.00 & 11.12 & 22.02 & & & 13.16 \\
\hline Muricidae (Muricidae) & & & & & & 27.53 & 0.03 & 72.45 \\
\hline Myctophidae (Lanternfishes) & 10.98 & 10.85 & 67.31 & 10.86 & & & & \\
\hline Myidae (Myidae) & & & & & & 20.06 & 0.16 & 79.78 \\
\hline Myliobatidae (Eagle rays) & & & 67.75 & & 27.75 & & & 4.50 \\
\hline Mytilidae (Sea mussels nei) & & & & & & 34.51 & 0.49 & 64.99 \\
\hline Myxinidae (Hagfishes) & 35.00 & 32.00 & & 33.00 & & & & \\
\hline Nemipteridae (Threadfin breams, Whiptail breams) & & & 100.00 & & & & & \\
\hline Nephropidae (True lobsters,lobsterettes nei) & & & 28.93 & & & & 71.07 & \\
\hline Normanichthyidae (Normanichthyidae) & & & 50.94 & 24.91 & 24.15 & & & \\
\hline Ommastrephidae (Squids nei) & & 1.03 & 30.66 & 59.34 & 8.97 & & & \\
\hline
\end{tabular}




\begin{tabular}{|c|c|c|c|c|c|c|c|c|}
\hline Family & Seine & $\begin{array}{c}\text { Midwater } \\
\text { trawl }\end{array}$ & $\begin{array}{c}\text { Bottom } \\
\text { trawl }\end{array}$ & Gillnet & $\begin{array}{c}\text { Hook } \\
\text { and line }\end{array}$ & Dredge & Trap & Other \\
\hline Ophidiidae (Cusk-eels) & & & 85.36 & 7.65 & 6.99 & & & \\
\hline Oreosomatidae (Oreos) & & & 100.00 & & & & & \\
\hline Osmeridae (Smelts) & 99.84 & 0.04 & 0.06 & 0.06 & & & & \\
\hline Ostraciidae (Boxfishes (cowfish and trunkfish)) & & 1.11 & 13.34 & 1.00 & 2.86 & & & 81.69 \\
\hline Ostreoidae (Flat and cupped oysters) & & & & & & 99.54 & & 0.46 \\
\hline Palaemonidae (Palaemonid shrimps nei) & & & 100.00 & & & & & \\
\hline Palinuridae (Spiny lobsters) & & & 0.07 & & & & 99.93 & \\
\hline Pandalidae (Pandalidae) & & & 100.00 & & & & & \\
\hline Paralepididae (Barracudinas) & & & 100.00 & & & & & \\
\hline Paralichthyidae (Large-tooth flounders) & & & 64.28 & 12.20 & 23.52 & & & \\
\hline Patellidae & & & & & & 31.19 & & 68.81 \\
\hline Pectinidae (Scallops nei) & & & & & & 100.00 & & \\
\hline Penaeidae (Penaeid shrimps) & & & 100.00 & & & & & \\
\hline Pentacerotidae (Armorheads) & 31.20 & 32.02 & 2.22 & 1.73 & 6.52 & & 26.30 & \\
\hline Percichthyidae (Temperate basses) & 16.00 & & 17.00 & 34.00 & 33.00 & & & \\
\hline Petromyzontidae (Lampreys) & & 0.13 & 48.41 & 41.04 & 10.42 & & & \\
\hline Phycidae (Phycid hakes) & & 1.13 & 94.02 & 4.77 & 0.05 & & 0.03 & \\
\hline Pinguipedidae (Sandperches) & & & 100.00 & & & & & \\
\hline Platycephalidae (Flatheads) & 19.80 & & 19.20 & & 61.00 & & & \\
\hline Platytroctidae (Tubeshoulders) & & & 100.00 & & & & & \\
\hline Pleuronectidae (Righteye flounders) & 6.14 & & 76.26 & 8.83 & 8.76 & & & \\
\hline Plotosidae (Eeltail catfishes) & & 100.00 & & & & & & \\
\hline Polynemidae (Threadfins) & 19.84 & 4.34 & 26.62 & 23.45 & 25.76 & & & \\
\hline Polyprionidae (Wreckfishes) & & & & & 100.00 & & & \\
\hline Pomacanthidae (Angelfishes) & & & 33.33 & & 66.67 & & & \\
\hline Pomatomidae (Bluefishes) & & & & & 100.00 & & & \\
\hline Portunidae (Swimming crabs) & & & 30.12 & 0.41 & & & 69.46 & \\
\hline Priacanthidae (Bigeyes or catalufas) & 0.03 & & 69.01 & 14.02 & 16.94 & & & \\
\hline Pristidae (Sawfishes) & & & 37.97 & 37.26 & 24.77 & & & \\
\hline Psettodidae (Psettodids) & & & 62.35 & 12.89 & 24.75 & & & \\
\hline Rajidae (Skates) & & & 100.00 & & & & & \\
\hline
\end{tabular}




\begin{tabular}{|c|c|c|c|c|c|c|c|c|}
\hline Family & Seine & $\begin{array}{c}\text { Midwater } \\
\text { trawl }\end{array}$ & $\begin{array}{c}\text { Bottom } \\
\text { trawl }\end{array}$ & Gillnet & $\begin{array}{c}\text { Hook } \\
\text { and line }\end{array}$ & Dredge & Trap & Other \\
\hline Regalecidae (Oarfishes) & 19.39 & & & 24.93 & 55.68 & & & \\
\hline Rhinobatidae (Guitarfishes) & & & 51.65 & & 25.77 & & & 22.58 \\
\hline Rhinochimaeridae (Longnose chimaeras) & & & 100.00 & & & & & \\
\hline Salmonidae (Salmonids) & 33.69 & 31.89 & 0.28 & 33.23 & 0.56 & & 0.34 & \\
\hline Scalpellidae (Barnicles) & & & & & & 31.19 & & 68.81 \\
\hline Scaridae (Parrotfishes) & & 6.52 & 2.68 & 25.46 & 23.78 & & 9.38 & 32.20 \\
\hline Scatophagidae (Scats) & 41.12 & 19.70 & 36.51 & & 2.67 & & & \\
\hline Sciaenidae (Drums or croakers) & 2.97 & 63.69 & 25.66 & 3.37 & 3.17 & & 0.81 & 0.33 \\
\hline Scomberesocidae (Sauries) & & & & 100.00 & & & & \\
\hline Scombridae (Mackerels, tunas, bonitos) & 57.46 & 1.96 & 0.01 & 8.16 & 28.98 & & 2.39 & 1.04 \\
\hline Scophthalmidae (Scophthalmidae) & & & 70.67 & 27.80 & 1.53 & & & \\
\hline Scorpaenidae (Scorpionfishes or rockfishes) & & & 35.00 & 33.00 & 32.00 & & & \\
\hline Scyliorhinidae (Cat sharks) & & & 34.31 & 37.98 & 27.71 & & & \\
\hline Scyllaridae (Slipper lobsters nei) & & & & & & & 100.00 & \\
\hline Sebastidae (Rockfishes, rockcods and thornyheads) & & & 46.66 & 19.00 & 34.33 & & & \\
\hline Sepiidae (Cuttlefishes) & & & 100.00 & & & & & \\
\hline Sergestidae (Sergestid shrimps nei) & & & 20.54 & & & & & 79.46 \\
\hline Serranidae (Sea basses: groupers and fairy basslets) & & 0.01 & 5.18 & & 94.74 & & & 0.07 \\
\hline Setarchidae (Setarchidae) & & & 50.00 & & & & 50.00 & \\
\hline Sicyoniidae (Sicyoniidae) & & & 100.00 & & & & & \\
\hline Siganidae (Rabbitfishes) & & & & 50.00 & & & 50.00 & \\
\hline Sillaginidae (Smelt-whitings) & & & & & & & & 100.00 \\
\hline Soleidae (Soles) & & & 100.00 & & & & & \\
\hline Solenidae (Razor clams, knife clams) & & & & & & 71.22 & 0.58 & 28.19 \\
\hline Solenoceridae (Solenocerid shrimps) & & & 96.36 & & & & & 3.64 \\
\hline Sparidae (Porgies) & & 28.63 & 38.83 & & 32.55 & & & \\
\hline Sphyraenidae (Barracudas) & & & & & 100.00 & & & \\
\hline Sphyrnidae (Hammerhead, bonnethead, scoophead shark) & & & 28.77 & 45.42 & 25.81 & & & \\
\hline Squalidae (Dogfish sharks) & & & 100.00 & & & & & \\
\hline Squatinidae (Angel sharks) & & & 3.22 & 93.64 & 3.14 & & & \\
\hline Squillidae (Squillids nei) & & & 94.01 & & & & & 5.99 \\
\hline Sternoptychidae (Sternoptychidae) & & & 100.00 & & & & & \\
\hline Stichopodidae (Stichopodidae) & & & & & & 50.61 & 20.55 & 28.84 \\
\hline Stomiidae (Barbeled dragonfishes) & 67.00 & 33.00 & & & & & & \\
\hline
\end{tabular}




\begin{tabular}{|c|c|c|c|c|c|c|c|c|}
\hline Family & Seine & $\begin{array}{c}\text { Midwater } \\
\text { trawl }\end{array}$ & $\begin{array}{c}\text { Bottom } \\
\text { trawl }\end{array}$ & Gillnet & $\begin{array}{c}\text { Hook } \\
\text { and line }\end{array}$ & Dredge & Trap & Other \\
\hline Stromateidae (Butterfishes) & & 0.22 & 73.55 & 12.58 & 0.14 & & 0.17 & 13.34 \\
\hline Strombidae (Strombidae) & & & & & & 60.05 & 4.56 & 35.39 \\
\hline Strongylocentrotidae (Strongylocentrotidae) & & & & & & & & 100.00 \\
\hline Synodontidae (Lizardfishes) & 29.67 & & 10.40 & 30.84 & & & & 29.09 \\
\hline Terapontidae (Grunters or tigerperches, thornfishes) & 18.24 & 21.38 & 21.26 & 21.13 & & & & 17.99 \\
\hline Tetraodontidae (Puffers) & 13.23 & 20.09 & 27.89 & 17.72 & 13.42 & & 1.22 & 6.43 \\
\hline Torpedinidae (Electric rays) & & & 87.37 & & 10.57 & & & 2.06 \\
\hline Trachichthyidae (Slimeheads) & & & 100.00 & & & & & \\
\hline Trachinidae (Weeverfishes) & 0.01 & 30.25 & 29.58 & 26.48 & 13.68 & & & \\
\hline Trachipteridae (Ribbonfishes) & 19.09 & 0.06 & & 25.51 & 55.33 & & & \\
\hline Triakidae (Houndsharks) & & & 32.00 & 33.00 & 35.00 & & & \\
\hline Trichiuridae (Cutlassfishes) & 3.53 & 92.53 & 0.29 & 3.53 & 0.12 & & & \\
\hline Trichodontidae (Sandfishes) & & 35.70 & 29.90 & 19.76 & 14.64 & & & \\
\hline Triglidae (Searobins) & & & 100.00 & & & & & \\
\hline Turbinidae (Turbin shells) & & & & & & 100.00 & & \\
\hline Veneridae (Venus clams nei) & & & & & & 98.87 & & 1.13 \\
\hline Volutidae & & & & & & 48.34 & 0.76 & 50.90 \\
\hline Xanthidae (Xanthidae) & & & & & & & 100.00 & \\
\hline Xiphiidae (Swordfish) & 32.00 & & & & 68.00 & & & \\
\hline Xiphosura (Xiphosura) & & & & & & 20.00 & & 80.00 \\
\hline Zeidae (Dories) & 4.62 & 0.09 & 94.76 & 0.26 & 0.27 & & & \\
\hline Zoarcidae (Eelpouts) & & 0.10 & 21.86 & 0.06 & 0.04 & & & 77.94 \\
\hline
\end{tabular}


Appendix 3. Cumulative catch by family and taxon associated with trawl or dredge gear from 1950 to 2001 inclusive in tonnes. Listings are by alphabetical order by family. Taxa with catches of less than one tonne per year on average were not included. This material is available on-line at http://wWw.seaaroundus.org/report/fcrr_12_6_appendix3.pdf 